Chapter 9

\title{
Cutting-Edge Regenerative Medicine Technologies for the Treatment of Heart Valve Calcification
}

\author{
Laura lop and Gino Gerosa \\ Additional information is available at the end of the chapter \\ http://dx.doi.org/10.5772/55327
}

\section{Introduction}

An early attempt of designing a valvular device was made already in 1513 by Leonardo da Vinci, who depicted the appearance of a prosthetic aortic valve to be reproduced in glass material [1].

The first real manufacture of valve substitutes goes back to the ' 50 s of the previous century, when the application in heterotopic position of an aortic mechanical valve by Hufnagel and colleagues triggered the beginning of the surgical therapeutic era of valvulopathies [2]. It was however the contribution of Harken, Starr and Edwards to demonstrate the feasibility of orthotopic valve replacement with these early devices [3]. Since then, several mechanical and bioprosthetic replacements have been proposed as valve substitutes. Still, these solutions are not meeting important prerequisites.

Heart valve tissue engineering and, later, tissue-guided regeneration have been proposed to overcome the limitations associated to current valve substitutes. Principles, preclinical and clinical models of each approach are discussed in this chapter, together to the diverse improving strategies for the final achievement of viable and functional aortic valve substitutes.

\section{Tissue engineering}

The different drawbacks related to commercial replacement devices compromise their durability once in the patient and have shift the attention of cardiac surgeons and biomedical engineers towards a new therapeutic concept: heart valve tissue engineering. The first general definition of this approach has been proposed by Langer and Vacanti, as the in vitro creation 
of a viable tissue by combining separate elements, i.e. cells plus an extracellular matrix (ECM), properly conditioned to attain the correct mature function [4]. This universal paradigm has to be applied also to the reconstruction of the valve tissue. The rationale is to achieve the ability to construct in vitro a valve with adequate biomechanical properties, good hemodynamic performance, vital competence, growth/remodelling permissiveness and lack of inflammatory/immunological reactions. Such researches have required the synergistic application of different scientific disciplines, from cell biology to engineering and surgery. In vitro valve creation is commonly pursued via two different methods diverging for the starter matrix.

\subsection{Biomaterial scaffolds}

\subsubsection{Polymeric materials}

The choice of the ECM scaffold is not only a distinction parameter among diverse approaches, but also essential for the successful realization of tissue-engineered heart valves (TEHVs). ECM is able to establish the necessary 3D configuration and guides cell attachment and structural development of the new tissue.

Synthetic materials have often represented the privileged option in TEHV formulations. Biopolymers as aliphatic polyesters, polyhydroxyalcanoates or different polyurethane compounds have been preferentially employed, providing scaffolds with controllable chemophysical characteristics as reproducibility, porousness and biodegradability rate. The chosen biomaterials have to respond to important requirements, as good cell-affinity and adequate structural architecture able to sustain the organ mechanics. To enable cell adhesion and spreading in the selected biopolymeric mesh, the modulation of porousness until $90 \%$ achievement is recommended [5].

In particular, most of these materials offer a further regenerative advantage also thanks to the good immunotolerance induced in the host body. In fact, after an initial guiding effect, the non-natural material is progressively degraded by colonizing cells, which in turn operate a new matrix synthesis. The process results in a newly produced tissue of completely autologous origin.

First generation polymeric heart valves were designed to overcome the poor durability and excessive wear shown by Teflon fabric-composed substitutes. These more rigid valves, with caged-ball or low-profile design, were based either on metals, like titanium or stellite 21, or on silicone with fixed fabric sewing rings. While metallic devices mostly presented difficulties in the insertion phase, elastomeric ball valves demonstrated less stability in the mid/long-term evaluation [6]. Polyurethanes were lately proposed for their relatively good haemodynamic behaviour especially in contact with blood cells and indeed for their easy manipulable chemical structure $[7,8]$.

Again, biostability represented the major drawback associated to these elastomers together to the high calcification potential: polyester, polyether and polycarbonate urethanes were sequentially suggested for valve fabrication with minor biodegradation, but still insufficient stability [9]. The introduction of further chemical groups and other modifications in 
the polymer segments has been carried out and is still under study to improve the durability of polyurethane-based devices in vivo $[8,10]$. In particular, when modified with polyhedral oligomeric silsesquioxanes (POSS), polycarbonate urethane-composed polymeric substitutes offer improved biological and hydrodynamic functioning in respect to bioprosthetic valves [11].

Shinoka et al. firstly reported in 1995 the application of aliphatic polyesters in TEHV formulation. The constructs were composed of polyglactin, polyglycolic acid (PGA) or polylactic acid (PLA) [12-14]. The scarce pliability of these biomaterials did not allow, however, a perfect shape modelling [15]. Conversely, polyhydroxyalcanoates, as polyhydroxyoctanoate (PHA) mixed or not with poly-4-hydroxybutyrate (PH4B), have demonstrated better thermoplastic proficiencies: a polyester group combined with bacterial-derived hydroxyacids is the chemical composition of these last polymers [16,17].

Polystyrene/polyisobutylene compounds were also developed for cardiovascular structure fabrication, showing superior resistance to the high environmental heart valve stresses [18].

Novel promising biopolymers are currently tested to better mimic chemo-physical properties of native heart valves: inter alia, polyvinyl alcohol-bacterial cellulose-based hydrogels can be opportunely modelled for a broad range of tuneable mechanical properties [19].

Contemporary procedures for polymeric aortic heart valve fabrication must rely on optimal tricuspid design, used as template for successive valve production. Multiple dip-coatings into poorly concentrated polymeric solutions have as major drawback inhomogeneous tissue thickness.

Another manufacturing technique combines the use of solvent and thermal treatment to properly shape polymeric films in a desired arrangement. Tri-dimensional models, additionally created through direct laser 'recording' in photo-sensitive polymers, act as blueprint for successive casting of hot biopolymers, which will assume the chosen conformation during chilling [20]. Similarly, injection systems assisted by hot/cold baths can be applied to the same aim [21].

\subsubsection{Decellularized extracellular matrices}

Despite the evident ability of these biopolymers to undergo cell remodelling, a proper mature, cell-operated tissue architectural reconstitution might require a chemo-mechanical stimulation for a long time. Often, to the best of their biostability and mechanical behaviour, biopolymeric heart valves do not develop a trilaminate structure and remarkably, the elastin network in leaflet layer ventricularis and wall media can be inconsistently achieved.

On this account, another research stream inside the heart valve tissue engineering approach prefers the usage of animal-derived decellularized scaffolds. A suitable decellularization procedure allows the removal of xenogeneic cells, maintaining all the fibre composition and distribution of the natural ECM. In addition, as further advantage in respect to commonly produced bioprostheses, the treatment with glutaraldehyde can be skipped following the absence of xenogeneic cells. The avoidance of this cytotoxic agent enables remodelling 
processes to occur by providing a cell-friendly milieu, where viable engrafting elements are able to accomplish synthetic and contractile functions with extracellular matrix continuous remodelling.

Cell-freed natural matrices can be realised by means of several methods: trypsin-based enzymatic and detergent decellularization procedures are only two examples of the proposed treatments. Most decellularizing protocols take advantage of a combined mechanical and chemical tissue handling to ease cell removal.

Grauss and colleagues interestingly compared various protocols currently applied to decellularize porcine aortic heart valves and verified that the combination of trypsin and Triton X-100, an anionic detergent, could be able to provoke a loss of matrix integrity [22]. Not only the enzymatic treatment with trypsin can induce elastin defragmentation, but also the use of sodium dodecyl sulphate can end out with a similar deleterious effect [23]. Conversely, the adoption of sodium cholate- and deoxycholate-based methods allows the achievement of fully nude matrices, able to be cell-recolonized in vitro and/or in vivo even for clinical implantation [23-28].

Besides native heart valves, another natural tissue has been regarded with attention for the production of animal-derived acellular scaffolds. Pericardium has been extensively applied in bioprosthetic manufacturing thanks to its biocompatible, mechanical and biological properties, entirely suitable for long-lasting heart valve substitutes. More often of bovine origin, this tissue partially differs from a native heart valve for its low cellularity and extremely compacted ECM, raising the question on which decellularization process can best convey the optimal outcome [29]. With regards to this tissue, the comparative analysis developed by Yang et al. revealed a superior decellularizing and preserving effect of enzymatic/detergent treatment or trypsin alone on Triton X100/sodium-deoxycholate-based extraction.

Sodium cholate demonstrates instead a less aggressive behaviour towards the pericardial tissue providing analogous results to its application on native semilunar heart valves [30].

Together to the elimination of xenogeneic cells, a variable depletion in the glycosaminoglycan (GAG) content is usually observed after decellularization procedure. GAGs play a significant viscoelastic role by mitigating valve stress during flexion: their highly hydrophilic nature allows, in fact, the hydration of the spongiosa layer in this cycle phase. Indeed, several biological processes appear to be modulated by GAGs, therefore their loss has profound consequences in the mechanical behaviour and in the cellular functions of successively repopulated scaffolds [31]. Associated to GAG content is also the hydrated state of the tissue: a reduction in hydration following decellularization can induce collapse of collagen fibres and introduces a less suitable environment for colonizing cells [32], 33].

While GAG and water preservation is pivotal, an opposite decellularizing effect is expected as far as DNA/RNA content. Similar to cell membrane residues, the phosphate groups of the nucleic acid backbone behave as powerful calcification triggers [34]. Aspecific endonucleases are often applied as efficient tools for the complete removal of nucleic acid debris [25-26]. 
Extracting processes should be hence developed ad hoc depending on the specific tissue to use as starter matrix, otherwise adversely affecting the original mechanical and bioactive properties of the natural ECM.

In addition, the realization of viable constructs must not be regardless of detergent scaffold retention. Incomplete washout of detergents could induce the creation of a toxic microenvironment for engrafting cells. In vitro evaluations should be critically performed in respect to each decellularization procedure currently applied [unpublished data, 35, 36].

\subsection{Cells}

Cells embody the second key-component of a TEHV: it is this element that provides viability to the ECM and consequently permits its remodelling and maturation towards a functional organ. Furthermore, the use of cell elements of allogeneic or autologous source can prevent from non-self reactions towards synthetic biomaterials or decellularized natural tissues.

\subsubsection{Differentiated cells}

For a similar selection principle operated by those researchers preferring the more committed animal-derived matrix, endothelial cells, fibroblasts, myofibroblasts and/or smooth muscle cells isolated from vascular or valve conduits have been extensively utilized to seed nude matrices and obtain both endothelial coverage with antithrombotic activity and tissue repopulation [24, 37].

Endothelial cells (ECs) were first applied in the '90s to test the feasibility of endothelialisation on Biomer and Mitrathane thromboresistant polyurethane ureas in response to physiological shear stress [38]. Commonly harvested from cardiovascular structures, as adult saphenous or more immature umbilical veins, endothelial cells were also seeded onto bioprosthetic heart valves to increase their low thrombogenic properties [39]. In an analogous fashion, a previous endothelial coverage on harshly decellularized native tissues can avert in vivo thromboembolic events, related to basal membrane damage/loss resulting in collagen fibres exposure.

More frequently, ECs were employed in combination to other cell elements, as for example myo/fibroblasts. A sequential seeding of fibroblasts and ECs was demonstrated effective in the in vitro creation of tissue-engineered valve constructs endowed with appropriate cell topography [40]. However, the district of fibroblast cell origin is able to significantly affect the degree of recellularization with better outcome associated to the usage of arterial myofibroblasts rather than of dermal fibroblasts [41, 42].

Valve fibroblasts, known as valve interstitial cells (VICs) for their cusp origin, have been successfully employed as sole repopulating cell population, exhibiting unmodified proliferative and synthetic abilities once engrafted in decellularized scaffolds [24].

While dissimilar to VICs, smooth muscle cells of vascular derivation (vSMCs) can be chemically manipulated with epidermal growth factor (EGF), platelet-derived growth factor (PDGF) and transforming growth factor beta-1 (TGF-beta1) for a phenotypic switch towards leaflet cells [43]. 


\subsubsection{Stem cells and progenitors}

Marrow stromal cells, umbilical cord myofibroblasts and progenitor cells, chorionic villiderived cells and placenta or amniotic fluid progenitors share not only the potential to transdifferentiate in valve phenotypes after appropriate stimulation, but are also associated to several positive aspects, making them particularly attractive for bioengineering applications [25, 44-46].

Stem and progenitor cells are now of relatively safe isolation from foetal and neonatal tissues, such as amniotic fluid, chorionic villi or umbilical cord. Most of them demonstrate mesenchymal properties, potentiated by higher cell plasticity in relation to their immature state. The embryonic-like phenotype, possessed by these early precursors, can be 'frozen' in cell banks at its genuine isolation state without further differentiation/ maturation and loss of stemness [45, 47-51].

While neonatal progenitor cells can be cryopreserved at birth in view of a future use, adult bone marrow-derived cells, and especially their mesenchymal compartment, can be easily harvested from the same cardiopathic patient for a fully autologous TEHV or even employed for the creation of allogeneic constructs [25], with no risk of cell rejection thanks to their beneficial immunomodulatory properties $[52,53]$. MSCs reside virtually in all post-natal body departments, as for example adipose tissue or dermis [54,55]. MSCs obtained from bone marrow (BM-MSCs) offer some advantages over other stem or progenitor cells in terms of their prospects for use in routine clinical practice, i.e. relatively simple protocols for their isolation, storage and in vitro expansion and a surprising phenotypic resemblance to valve cells [56, 57]. Indeed, their phenotypic convertibility into ECs, fibroblasts/myofibroblasts and SMCs might allow in a single step-seeding procedure to reconstruct the cell geographic distribution typical of valve cusps [25, 47, 58-60]. hBM-MSCs display a repertoire of molecules that may be relevant to their adhesion and penetration in synthetic or decellularized scaffolds, including b1-integrin (which plays a pivotal role by mediating cell-ECM interactions), CD54, CD105 and CD44 (which act cooperatively in cell homing via binding to hyaluronan, the major non-protein glycosaminoglycan of the ECM) [25].

Another cell type with attractive potential for heart valve tissue engineering is the equally rare, but more easily harvestable circulating fraction of endothelial progenitor cells (EPCs). Commonly isolated from the peripheral blood with a simple venous drawing (i.e. umbilical vein), these progenitors have a high proliferation activity and can commit to transform into a mesenchymal phenotype, reminiscent of the endothelial-mesenchyme transition during embryonic valve development [61-63].

\subsubsection{Bioreactors}

Scaffolds and cells do not represent alone sufficient components for a successful TEHV, but conditioning is indispensable to achieve a perfect maturation of the construct prior to implantation. This last step in manufacturing a viable valve can be guaranteed by the use of bioreactors able to submit it to physiological pressures and flow [64, 65]. Besides mechanical stimulation, 
the addition of specific chemicals can further train tissue-engineered valve constructs towards their proper functionality [66].

Firstly developed devices were very simple systems based on common or modified petri supports, in which TEHVs could be statically cultured.

The introduction of a dynamic conditioning was hence operated to improve cell engraftment and differentiation through the assemblage of two chambers: one for lodging the valvular construct, the other mimicking ventricular function. Connected to an air pump, the ventriclelike compartment can exert defined hydrodynamic settings in terms of flow and pressure. Diaphragms of different materials, as for example silicone, separate the two chambers and are displaced periodically by air influx [16].

The small size of the device has been primarily regarded for ensuring long-term culturing in defined temperature/gaseous environment. A compact system can, in fact, easily fit in an incubator, where $\mathrm{CO}_{2}$ saturation, humidity and temperature are already set for cell culture [16]. To this aim, the implementation with gas sensors directly placed in the device can result in a superior chemical control of $\mathrm{CO}_{2}, \mathrm{~N}_{2}, \mathrm{O}_{2}$, glucose and lactate $[67,68]$.

Single specific mechanical stresses were successively applied to better induce tissue maturation and, furthermost, to activate endothelial-mesenchymal transformation. Laminar flow-, flexure- and cyclic strain-based stimulations could have profound effects on mechanical stiffness, collagen synthesis and alignment in the tissue-engineered valve [69-71].

A three-chamber bioreactor was developed by Sierad et al. in 2010 to respect previously indicated criteria and other important conditions, as easy valve mounting, physiological stimulation (transvalvular pressures, pulsatile forces, flow rate, frequency, stroke rate and shear stresses) and full control over parameters. Absence of toxic or degradable fabrication materials, maximum visibility, together to ease of sterilization and waste removal, further increase the yield of repeatable results. Compliance and reservoir tanks with sterile filters for gas exchange, one-way and resistance valves, pressure transducers, a web-cam and a ventilator pump complement this efficient system [72].

\subsubsection{In Vitro applications}

The reconstruction of a heart valve tissue in a plate dish was first endeavoured by the Bostonian teams of R. Langer, J.P. Vacanti and J.E. Jr Mayer, who published in 1995 the results of this pioneering work [12]. Vascular cells, outgrown from ovine neonatal femoral artery explants, were divided into two populations by LDL selection. LDL-negative SMCs/fibroblasts and LDL-positive ECs were sequentially seeded onto polyglycolic acid/polyglatin scaffolds in a 2week-long procedure. Later, different cells and polymers were combined in the most efficient valve tissue combinations [41, 73, 74]. The introduction of PHAs, PH4B/PHAs and pulsatile flow conditioning in a bioreactor for heart valve construction allowed the attainment of more pliable scaffolds. After dynamic seeding, cells demonstrated to be actively involved in GAG and collagen synthesis, leading to an autologous replacement of the polymeric mesh $[16,75$, 76]. PH4B/PHA became, in particular, the most promising scaffold for several successful TEHV approaches relying on diverse stem cells [44, 45, 49, 77-79]. 
Elastomeric poly(glycerol sebacate) scaffolds treated with multiple coating strategies based on ECM-derived proteins allowed adhesion and transdifferentiation of EPCs $[61,80]$.

In respect to the application of bioabsorbable polymers, the other TEHV modality, founded on natural ECMs, was experimented some years later. After the development of various decellularizing treatments, the combination with differentiated cells, as ECs and VICs, was able to generate directly in vitro by static conditioning surrogates of early heart valve tissues $[24,81]$. As well as polymeric TEHVs, cell-repopulated decellularized ECMs were positively remodelled after dynamic stimulation with proper mechanical signals. In this case, actually, also elastin content was demonstrated to increase [82-84].

The usage of stem cells as cell source for the engineering of plain ECMs led to even better in vitro outcomes. Multipotent differentiation potential of human bone marrow MSCs can represent the ideal characteristic for complete repopulation of natural valve matrices. MSC engrafting ability was evaluated on decellularized porcine and human scaffolds. In both considered interactions, stem cells were able to adhere, spread within the ECM and transdifferentiate towards typical valve phenotypes (ECs, VICs). Collagen, GAG and elastin synthesis was indeed activated in engrafted cells, which tend to distribute similarly to the original valve cell topography. It was, however, the homotypic combination to better favour MSC-to-SMC conversion in the ventricularis layer [25].

\section{Tissue regeneration}

TEHV is not the sole approach investigated to obtain new viable valve devices: tissue-guided regeneration has been proposed as an alternative method for in vivo direct tissue reconstruction, by exploiting ECM instructive abilities. Once eliminated the allogeneic or xenogeneic cell component through decellularizing treatment, the fibre mesh still maintains biomechanical proficiency assuring in vivo prompt restoration of hydrodynamic performance. Furthermore, in the body, conceived as physiological bioreactor, naked natural scaffolds recruit recipient's cells thanks to their chemo-attractant properties. Positive aspects associated with this option should be identified in the possibility to construct autologous-like tissues, by skipping difficultly controllable procedures of cell seeding and chemo-mechanical stimulation in vitro.

Among the first experimental evidences, biomaterials, as patches of pure type I collagen, have been successfully introduced in the therapy of ischemic myocardium: once applied to the diseased tissue, the collagen sponge attracts progenitors and less undifferentiated cells, which in turn or alone are able to fully colonize it and start a cardiovascular transdifferentiation [85]. It is noteworthy to remember that these patches, either synthetic or cell-purified from biological tissues, have found FDA-approved applications as haemostatics or for skin reconstruction with excellent results [86].

A further surprising element for a positive consideration of this method has been given by Campbell and colleagues, who were able to obtain a tubular cell construct by implanting a polymeric tube in the animal peritoneal cavity. The newly formed tissue, pulled from the tube, 
had anatomical and histological resemblance to a quite mature blood vessel and it could be hence considered an optimal vascular substitute [87].

Also offering the opportunity to create tissue banks for ready-to-use devices at the moment of clinical need, the investigation on tissue-guided regenerated heart valves (TGRHVs) has particularly increased in recent years.

\section{Preclinical and clinical applications of tissue engineering and tissue regeneration approaches}

The preclinical proof-of-principle of TEHVs as valve substitutes has been demonstrated in the lamb model already with the polymeric bioconctructs firstly produced in vitro [12]. Vascular cell-repopulated polyglycolic acid/polyglactin matrices were implanted in the pulmonary position up to 21 days. Function assessment by Doppler echocardiography demonstrated no stenosis or regurgitation signs, even if a substantial leaflet thickness was reported.

Each subsequent modification in scaffold or cell types, as introduced by the same group, was generally tested in vivo, validating progressive functional improvements in transplanted lambs or sheep [41, 73, 74].

Further TEHVs applications in preclinical models were substantially based on the use of P4HB/ PHA with few exceptions, as electrospun polydioxanone [88]. In combination with stem cells of various stromal origins, $\mathrm{P} 4 \mathrm{HB} / \mathrm{PHA}$-formulated engineered tissues were evaluated in a long-term animal model, showing replacement of the exogenous matrix after nearly 8 weeks in vivo [16].

A MSC-engineered mesh of polyglycolic and polylactic acids was evaluated as autologous pulmonary valve replacement in juvenile sheep. The good performance of this in vitro generated construct could be appreciated in a long follow-up of 4 months with restoration of a native-like pulmonary heart valve [59].

Despite biomechanical stimulation induced optimal results in term of cell viability and differentiation almost independently from the cytotype utilised, combined polymer/cell-based efforts to obtain a valve substitute have usually failed in recreating the fibre arrangement of a native ECM. In fact, trilaminate distribution of collagens, GAGs and elastin has been reported only in few cases [88].

A finely organized ECM already exists in native heart valves and can be conserved after cell removal. After decellularization with trypsin/EDTA, heart valve conduits were seeded with ECs and myofibroblasts. Allogenically implanted in orthotopic position, they performed adequately. Ex vivo tissue analyses revealed surface endothelium reconstitution, myofibroblasts-mediated repopulation and ECM synthesis with no signs of inflammation and calcification [89]. 
Sole ECs were used to obtain in vitro endothelium coverage of ovine acellular scaffolds. After 6 months of in vivo evaluation, explanted tissues presented no calcifications as assessed by atomic absorption spectrometry [90].

Lutter et al. coated stented pulmonary valves with small interstinal submucosa, both pigderived and decellularized. These scaffolds, dynamically seeded in vitro with ECs and myofibroblasts, were deployed in orthotopic position by means of transcatheter assistance. Valve performance and macroscopic appearance demonstrated to be normal during in vivo and post-mortem evaluation [91].

Despite rare reports of deleterious therapeutic effects associated to TEHVs' implantation in humans [92], clinical application of these substitutes, attained by combination of acellular scaffolds and ECs or EPCs, reached already more than 10 years of experience with proved function and absence of calcifications [93, 94].

Another modality of heart valve tissue engineering has been more recently proposed. It is realized by means of a one-phase intraoperative approach. The rational of such a strategy rises from the necessity of a ready-to-apply TEHV, when the surgical therapy has to be promptly adopted with no time for in vitro cell seeding and bioreactor conditioning. Weber and colleagues implanted such prepared TEHVs in the RVOT of non-human primates through minimally invasive, transapical procedures. These polymeric trileaflet heart valves have been just seeded with unselected autologous bone marrow cells before the crimping necessary for valve insertion. After one month, the completely remodelled valves were still functioning [95]. Similarly conceived TEHVs demonstrated patency also in the aortic position, being able to sustain the higher pressure regimen of the systemic circulation [96,97]. Another in situ TEHV delivery has been applied by Vincentelli et al, by injecting mesenchymal stem cells into a just deployed decellularized heart valve. As element of comparison, they used acellular scaffolds: these ones showed equal performance and reconstructed tissue [98]. However, these are no more TE-, but TGRHVs.

The first attempt of tissue-guided heart valve regeneration has been challenged by the extensive work of Konertz and colleagues, who, moving from the classical paradigm of tissue engineering, compared the two methods. Common for each approach is only the application of the same decellularizing detergent, deoxy-cholic acid. By using an allogeneic decellularized valve for the reconstruction of the right ventricular outflow tract in sheep, they ascertained there was no need to seed the scaffolds prior to implantation, after the good repopulation observed at six months [99]. Follow-up of the valve function revealed increase in the annulus diameter in response to animal growth [100]. As further step to the clinic, they developed a xenogeneic model again with substitution of the autologous pulmonary valve, transferred in aortic position during Ross intervention. They tested porcine decellularized valves, called Matrix P, in a pig-to-sheep interaction. By comparison to sheep cryopreserved allografts, decellularized porcine valves demonstrated better valvular performance, decreased calcific potential and feasible tissue regeneration [101]. Another group compared the haemodynamic function of valve allografts, either cryopreserved and/or decellularized, verifying a reduced calcification tendency in the sheep implanted with decellularized matrices [102]. 
Equivalently promising results have been reported for the implantation of Triton X100/sodium cholate-decellularized allogeneic valves in the longest preclinical follow-up ever realized for a TGRHV. Evaluated in Vietnamese minipigs as RVOT replacements in heterotopic position, these acellular, alpha-gal-free certified valve substitutes have demonstrated good haemodynamic performance with low transvalvular gradients in a 15-month-long in vivo observation.

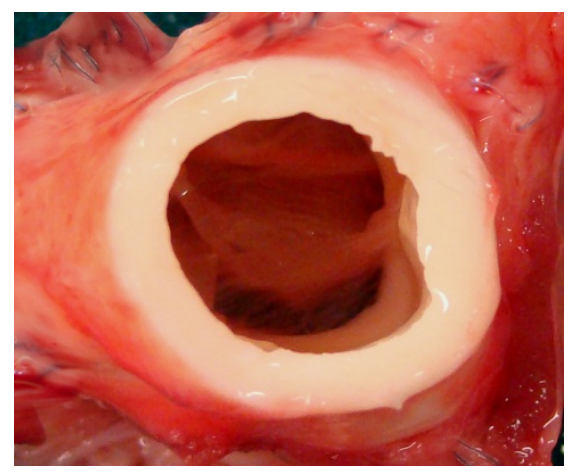

Figure 1. In vivo tissue-regenerated heart valve after 12 months of implantation in Vietnamese minipig

No calcification events could be appreciated within engrafted tissues by trans-thoracic echocardiography: these macroscopic observations found ex vivo confirmation by undetectable calcific foci after von Kossa staining. In addition, no inflammatory or immunogenic cells could be observed. A progressive repopulating process occurred in implanted valves: most tissues were endothelialised and engrafted by rare stem cells and numerous myo/fibroblasts, both highly proliferating and suggesting the onset of a smooth muscle cell conversion. Provision of oxygen and nutrients was again established by a dense capillary network and recreated vasa vasorum. Moreover, re-innervation aspects were also identified [26, 27].

Acellular allologous conduits were also favourably approved as aortic valve substitutes in a sheep model [103].

Few unfavourable outcomes with a TGRHV have been seldom disclosed. Two groups of heart valves, cryopreserved or decellularized and treated with an anticalcinosis devitalisation (digitonin and ethylenediaminetetraacetic acid), were tested in dogs by substituting an aorta fragment with the non-coronary sinus of the cusp allografts: albeit the lack of immune infiltrate in inserted decellularized specimens in contrast to cryopreserved ones, no engrafting of recipient's cells was observed in both cases [104].

The reasons for such different findings should first be searched in the used decellularization procedure for TGRHV production.

Apart from animal studies, allologeneic TGR approaches were also applied in humans with optimal outcomes. Decellularized allogeneic valves, as obtained with the deoxycholic acid procedure, were evaluated in 68 patients in the medium term for RVOT reconstruction in Ross aortic valve substitution. Up to 4 years, Costa et al. observed very low mortality (1, $4 \%$ ), a 
good valve function, both comparable with the cryopreserved allografts used as control, and a progressive engraftment - even if discontinuous [105].

TGR has been further practised as an alternative RVOT replacement strategy for human paediatric and young patients with confident results in a follow-up of more than 5 years. Freedom from re-intervention, lower transvalvular gradients and adaptive dimensional modifications in response to somatic growth have been reported from in vivo early-term comparison with pulmonary allografts [106]. In a just slighter observational window, allogeneic pulmonary valves were evaluated in a multicentre study with 342 patients undergoing RVOT reconstruction: improvement in haemodynamic function was registered for implanted valves and suggested to be related to decreased tissue antigenicity [107]. After a 5-year follow-up in 48 patients, Burch et al. put the accent on the relevance of the economic burden, related to the use of decellularized cryopreserved allografts in respect to their untreated counterparts [108].

Although good reported outcomes open the route for a promising treatment of heart valve failure, it will be imperative to reconsider therapeutic effects in a longer clinical evaluation, by taking into account also socio-economic considerations.

A debated note is, however, represented by the clinical application of unseeded decellularized xenogeneic tissues as valvular replacement solutions. In vivo infiltration of tissue-engineered Matrix $\mathrm{P}$ heart valves by human cells, not related to inflammatory or immune system, was observed in some explanted specimens [109]. These relevancies were at the basis of the pure Matrix P adoption in the clinical arena. Although favourable performance and lack of xenogeneic tissue-mediated immune reactions have been demonstrated by the same valvemanufacturing group in respect to current RVOT substitutes [110,111], controversial issues were evidenced after implantation of the same Matrix P valves in other studies [112, 113].

These reports, together with the dramatic results of the early failed Synergraft decellularized valves [114], should lower the speed in the human application of xenogeneic tissues-derived devices, moving a step backward to more robust human-like preclinical trials, as non-human primate animal models.

\section{New insights on heart valve regenerative medicine}

\subsection{Immunogenicity of xenogeneic tissues}

Allotransplantation has been widely consolidated as valid therapy to rescue a failed vital function, but the shortage of human cells, tissues and organs dramatically increases the waiting lists for replacement: in 2006, Eurotransplant referred almost 16.000 patients were attending to receive a substitute, while in the United States these ones were reaching the number of 90.000 [115]. The numerical entity of these registers is expected to sensitively grow during the near future. Surely, the employ of unlimitedly supplied, animal-derived organs could allow an immediate intervention to recover the lost function and in combination with bioengineering methodologies, might favour the achievement of human-like organs throughout strictly 
controlled fabrication procedures. So far, animal tissues fixed in glutaraldehyde have been the reserve to exploit at the time of clinical need. However, this should be no longer considered as viable route in accordance to vitality maintenance, above all for those organs that cannot perform a correct function in absence of a proper cell physiology. The use of non-human sources is accompanied by a major raising concern for a broad clinical application, i.e. the immunological barrier. For a donor-receiver mismatched allocombination, the most serious medical issue is the inability of accommodation and therefore the onset of chronic rejection, whose main manifestation, in the case of heart transplant, is graft vascular disease. This allotransplantation drawback is characterized by an unchanged gravity and entity in respect to 40 years ago, when this research line started to be investigated as possible treatment of endstage pathologies [116].

A peculiar atherosclerotic process interests the heart transplant with few calcifications, but increased cellularity and extracellular matrix deposition at the entire intimal level with a concentric distribution [117].

A similar event occurs in the xenotransplantation approach, where an even more severe expression is attended. Furthermore, in addition to a chronic response, antibody-mediated hyperacute rejection represents a dramatic hurdle to early-term xenograft survival, when a trans-species interaction has to be considered. By developing in a time period from minutes to hours in the pig-to-primate combination, hyperacute rejection, commonly defined as HAR, is a typical humoral immune response in vascularized organs with deposition of xenoreactive natural antibodies and complement activation [118]. Pig-to-primate xenotransplantation has properly enabled to discover the progression of delayed immunological answer to the cardiac graft (DXR): besides a strong humoral activity, acute cellular infiltrates and endothelium activation seriously compromise the function of newly transplanted organ [119].

\subsubsection{Alpha-gal and other xenoantigens}

Not well known - and in the last years very debated- is the real immunological trigger able to cause the complete loss of the xenograft during time. Probably the prompts of this phenomenon are not to be found in a unique opponent, but in more factors, which alone or in cooperation provoke it. One of the most powerful antigens is definitely Gal $\alpha 1-3 \mathrm{Gal} \beta 1-4 \mathrm{GlcNAc}$, commonly identified as $\alpha$-Gal. This oligosaccharide is a component of the glycoproteins and glycolipids, displayed on the surface of vascular endothelial cells in all mammals except apes, Old World monkeys and humans, unable to metabolize it for evolutionary gene silencing of the related enzyme $\alpha 1-3-G a l a c t o s y l t r a n s f e r a s e ~[120,121]$. Reaching an expression concentration of at least $10^{7}$ epitopes per pig cell, alpha-gal is recognized by human cells in a highly specific pattern soon after birth similarly to $\mathrm{ABO}$ antibodies. In fact, microorganisms colonizing or transiting through the intestinal flora express it on their surface and due also to the dietary use of animal-derived nourishment, 1\% of serum circulating IgGs are specifically directed against this epitope with a quite pure protective role against parasite and viral attacks $[122,123]$. Already at the end of the previous century, a restricted but well developed body of evidence considered alpha-gal as an immunogenic suspect, but it was only more recent the full demonstration of its causative role in HAR, by studying the pig-to-primate interaction 
[124]. Other important observations have been made available with this research about the amount of natural anti-pig antibodies in humans and their specific subclasses. At least $85 \%$ of humoral anti-pig players are specific for alpha-gal and belong to $\operatorname{IgG}$ and IgM classes: more recurrently, IgMs tend to deposit on the graft endothelium [124-126]. Anti-Gal antibodies have been shown to contribute both to HAR and lately DXR, if an initial tolerance regimen has been introduced [127].

Hence, the issue is unquestionably alarming for new therapeutic approaches of biomedicine using xenogeneic biological materials.

In order to face this problem, different strategies have been developed just from the observation of the glyco-composition differences between pig and human cells. In the endothelium of both species, $\mathrm{N}$-acetyllactosamine and sialic acid are expressed, but the human one -as previously mentioned- lacks alpha-gal and is characterized by the presence of $A B H-G a l \beta 1-4 G l c N A c \beta 1-R$ (ABO system) and a supplementary sugar, NeuGca2-3Gal $\beta 1-4 G l c N A c \beta 1-R$ (N-glycolylilneuraminic acid). Since the complete elimination of anti-Gal IgMs resulted in null complementmediated cytotoxicity by human serum without side effects on the IgG counterpart, various methods to deplete the whole range of anti-alpha gal antibodies have been tested.

First xenotransplantation experiments have been started in the 1960s, when the existence of alpha-gal and its antibodies was still ignored, however a decrease in xenoreaction could be achieved by perfusing the recipient's blood in a donor-specific organ, such as the liver, possessing high immunoadsorbent ability. Analogously, other depletion procedures have ameliorated the survival of the xenogeneic tissue, even if still at the initial developmental phases: plasma exchange and plasma perfusion through column systems based on specific protein interaction or on immunoaffinity could extend implant durability, but rarely for more than one month due to failed establishment of accommodation.

A more direct method, independent from external devices, is the intravenous approach based on similar affinity principles. Infused antibodies precisely targeting idiotypes of anti-gal humoral effectors, immunoglobulin (IVIG) or even oligosaccharides behave as silencers, by blocking -at least quite completely- any possible immunological response against alpha-gal. In the case of IVIG, it has been postulated an indirect beneficial role through the acceleration of IgG physiological catabolism and inhibition of macrophage function [126].

A further procedure inducing an accommodation state can be identified in the suppression of anti-gal cell effectors, by full depletion of B-lymphocytes and plasma cells. Methods proposed for this purpose are irradiation, pharmacological therapy, anti-B cells specific antibodies (mAbs) and immunotoxins. The irradiation of the entire body with the clinically used dose of 300 cGy does not result in a lethal condition, but provokes a transient B-cell ablation, whose effects are therefore time-limited. The administration of $\mathrm{mAbs}$ underlies a more selective way of action and benefits from clinical experiences completed in the haemato-oncological field. Anti-CD20 mAbs, for instance, have been used to treat baboons for 4 weeks: at the end of this course, a complete deficiency in B cells could be maintained both in bone marrow and peripheral blood for at least 3 months. A combination of immunotoxins, such as ricin A and sapporin, and mAbs can promote better ablation results [126]. In the transplantation setting, 
a wide line of investigation has been directed to discover chemical agents able to perform immunosuppressive effects. Even in xenografting, this kind of therapy seems to have a supporting role for other strategies in order to induce accommodation.

Cyclophosphamide is one of the most common pharmacological agents with this task: in heart transplant, function prolongation induced by this drug is positive without doubt, but many risks are associated with its permanent use, as leukopenia [128].

Alkylating agents, as melphalan, or DNA polymerase blockers, as zidovudine, or even enzymatic inhibitors, as methotrexate, have been analogously experimented with different results. The first ones are particularly interesting because they are quite the unique to target plasma cells. Although reducing anti-alpha gal IgGs, suppressive effects of zidovudine are not so important in a prospective clinical use. Methotrexate, on the contrary, appears to be a valid agent if added to other B cell-destroying therapies. In new-born baboons, mycophenolate mofetil (MMF), an inhibitor of the purine synthesis, has allowed, as therapeutic adjuvant, to prolong the survival of transplanted porcine hearts of at least the double time in respect to non-treated animals [129]. These results in themselves could not seem particularly appealing if compared to the effects of other drugs, but MMF is able to offer a similar efficacy in the face of lack of side consequences and seems very promising for future uses on xenotransplanted patients.

A special mention should be addressed to a therapeutic approach based on a quite new soluble glycoconjugate, GAS914, in combination with different drugs (among which MMF too). GAS594 has demonstrated a constant proficiency in lowering the titres of anti-gal IgGs and IgMs, and hence prolonging durability of transgenic porcine hearts transplanted in cynomolgus monkeys [130].

All these methods search to abate the recipient's response to this carbohydrate, but generally a certain refractoriness does not allow a long permanence of the xenograft and consequently provokes the inability to maintain the organ function [126].

\subsubsection{Animal humanization}

Alpha-gal-induced rejection could be possibly avoided also throughout the modulation of the donor tissue, i.e. by bioengineering the animal donor for elimination of antigenicity sources. Gene engineering techniques enable to introduce human genes directly in the animal genome. So-generated porcine transgenic cell lines expressing human $\alpha 1$, 2-fucosyltransferase display in their cell membranes more universal donor $\mathrm{O}$ antigens than alpha-gal epitopes, therefore evoke decreased antibody reactivity [131]. Genetically induced human decay-accelerating factor (hDAF) expression in animal grafts plays an inhibitory role in the onset of HAR [132]. Nevertheless, more incisive approaches are gene knocking down or out of $\alpha 1$, 3-galactosyltransferase (Galt). When transplanted in heterotopic position into immunosuppressed baboons, Galt-KO porcine hearts could survive in vivo for at least 6 months with graft surviving at least HAR, but failing for later complications [133]. 


\subsubsection{Decellularization strategies}

Xenoantigens are commonly accepted to be cell-derived, so the removal of membranes, where these epitopes are displayed, should definitely circumvent xenoreactions. Such a perspective could particularly fit the case of engineered arterial vessels or heart valves, based on decellularized tissues. When the first human paediatric implantations of plain porcine heart valves, produced in an industrialized and controlled manner, were performed, a severe inflammatory/ immune response provoked premature graft failure [114]. These dramatic events could be attributed to an incomplete cell removal: the same Authors imputed in residual alpha-Gal the responsibility of observed HAR occurrences and later, suggested the use of the detergent IGEPAL CA-630 for total extraction and correctly wash-out from treated heart valves [134].

More recently, clinical evaluations by Bloch et al. have revealed no IgG-mediated, but minor IgM-related responses towards decellularized valves in respect to common bioprostheses [111].

It is undeniably important to improve decellularization strategies for alpha-gal removal. Ex vivo investigations on bovine and porcine valve tissues revealed that alpha-Gal is not only expressed at the endothelial level of the leaflet surface coverage, but also by ECs lining the arterioles' vascular lumen at the cusp base [25]. Also some stromal cells in the interstitium display this antigen on their cell membrane [134].

Particular attention should be addressed to validate techniques used for alpha-gal revelation. The isolectin BSI-B4, commonly suggested in the literature as detector, gives consistent results only for fresh specimens, but displays an aspecific affinity when applied to decellularized leaflets. The affinity binding of BSI-B4 towards glucidic molecules contained in alpha-Gal epitopes is less stable than the link achieved by immunodetection with the highly specific antibody M86 [25].

For future applications in this field, implantable valve substitutes should be certified for alphagal subtraction. Furthermost, for the good manufacture practice of therapeutic strategies based on decellularized extracellular matrices, it would be of paramount importance to rely on specific assays able to quantitatively detect the residual amount of alpha-gal xenoantigens (i.e. M86-based alpha-gal ELISA test) [25, 135, 136].

\subsubsection{Decellularized scaffolds obtained from tissue-engineered constructs}

A completely new approach to overcome xenograft/allograft-related immunogenicity has been recently proposed, by drastically bypassing the use of non-human tissues. Dijkam et al. decellularized a previously tissue-engineered heart valve and demonstrated the feasibility of an in vitro regeneration guided by the acellular ECM. First, TEHVs were obtained by seeding vascular cells on poly-4-hydroxybutyrate/polyglycolic acid scaffolds and by dynamic conditioning. Then, cell removal was operated using a detergent-based treatment (Triton X100, sodium deoxycholate and EDTA), followed by endonuclease digestion. Decellularized matrices were consequently repopulated with MSCs and tested for haemodynamic performance through a simulated transapical implantation. Mechanical characteristics of acellular 
scaffolds were also evaluated. Considerably, obtained scaffolds could be conserved for up to 18 months without modifying their bioactivity and biomechanical properties [137].

While representing an absolutely novel therapeutic concept to solve immunologic issues, it is associated to some significant drawbacks. The procedure to generate such a fully biocompatible scaffold is quite long, complicated and depending on multiple conditionings.

By the way, by exploiting a controlled large-scale industrial production, it would be possible to manufacture off-the-shelf valve substitutes. The major limitation is represented, indeed, by the immature nature of fabricated scaffolds. As in other tissue engineering-based solutions, the synthesized ECM, rich in collagen and GAGs, risks to be deficient in resilience following the absence of an elastin network.

\subsection{Mimicking aortic valve formation}

\subsubsection{Valve cell progenitors: Possible surrogates and gene engineering for their generation}

In the development of cardiac valves, the endocardial cushions appear to be the primordial of the valvular leaflets and the membranous septa: they derive from regionalized expansions of extracellular matrix between cardiomyocyte sheets and endocardial cells of the cardiac tube. A subset of endothelial cells acquires specific abilities of delamination and invasion of the cardiac jelly, by assuming a typical mesenchymal phenotype, with high proliferative activity and able to remodel the cushions in definitive cusps. The work of Markwald and Colleagues about Endothelial-Mesenchymal Transition (EMT) first evidenced the involvement of soluble factors in the extracellular matrix and nevertheless a close myocardium-endothelium relationship, likely to emphasize the unique responsive property of endocardial cells to cardiomyocytes' mechanical and paracrine stimuli [138].

At the end of the developmental process, at least four are the cellular contributions which constitute the different valvular phenotypes: the myocardium, whose involvement is immediate in the formation of the atrioventricular valves; the endocardium, which undergoes an endothelial-mesenchymal transdifferentiation; the epicardium, contributing to the atrioventricular valves; and the neural crest cells, which migrate from the brachial arches to the distal outflow tract, participating to the aorto-pulmonary septation [139-141].

Excluding embryonic cells for ethical concerns, cells with EMT potentiality should be endowed with a certain degree of plasticity: as seen before, EPCs and MSCs, isolable from several tissue sources of various donor ages, could possess among other cell phenotypes these requisites and find, in fact, broad application in tissue engineering practices.

Not yet followed in heart valve manufacturing are two other modalities to achieve more committed valve cell lines. On one hand, it would be possible to introduce genome modifications in cells already applied in TEHVs to induce paracrine mechanisms able to foster cell differentiation. On this basis, VEGF-overexpressing stem cells transplanted in the ischemic myocardium induced an improvement in vascularization [142]. Indeed, MSCs engineered to express Akt did not only participate to the repair of the infarcted heart, but also improved cardiac function [143]. 
The other more attracting frontier in advanced TEHV formulations is represented by the conversion of adult somatic cells to pluripotent stem cells (iPSCs) mediated by gene engineering. Cellular reprogramming to pluripotency is induced by the ectopic expression of 4 factors, i.e. Klf-4, c-Myc, Oct4 and Sox2 [144], rendering these cells phenotypically similar to embryonic stem cells but for an ethically acceptable use. iPSC cardiovascular applications range from the modelling of congenital cardiac diseases to the heart restoration after myocardial infarction $[145,146]$. iPSC-based tissue-engineered heart valves could represent new powerful tools for the therapy of valvulopathies both as replacement solutions and as in vitro 3D valvular disease models.

\subsubsection{Scaffold incorporation of growth factors}

The close observation of the molecular events undergoing in heart valve formation would give specificindications on which signals bioengineered constructs could benefit for their maturation.

Endocardial cells undergo a profound phenotypic switch loosing the initial morphology, specific surface molecule expression and ability of acetylated-low density lipoprotein uptake in favour of a contractile, invasive profile. Transforming growth factor 1 and 2 (TGF-beta1 and 2), vascular endothelial growth factor (VEGF), bone morphogenetic protein 2 (BMP-2), mitogen-activated protein kinase 3 (MEKK3) and Notch1 are known to activate and strictly regulate EMT by direct control of Wnt/beta-catenin pathway. In addition, other molecular pathways are involved in heart valve development and the high complexity of regulation can be appreciated in the following chart (Figure 2):

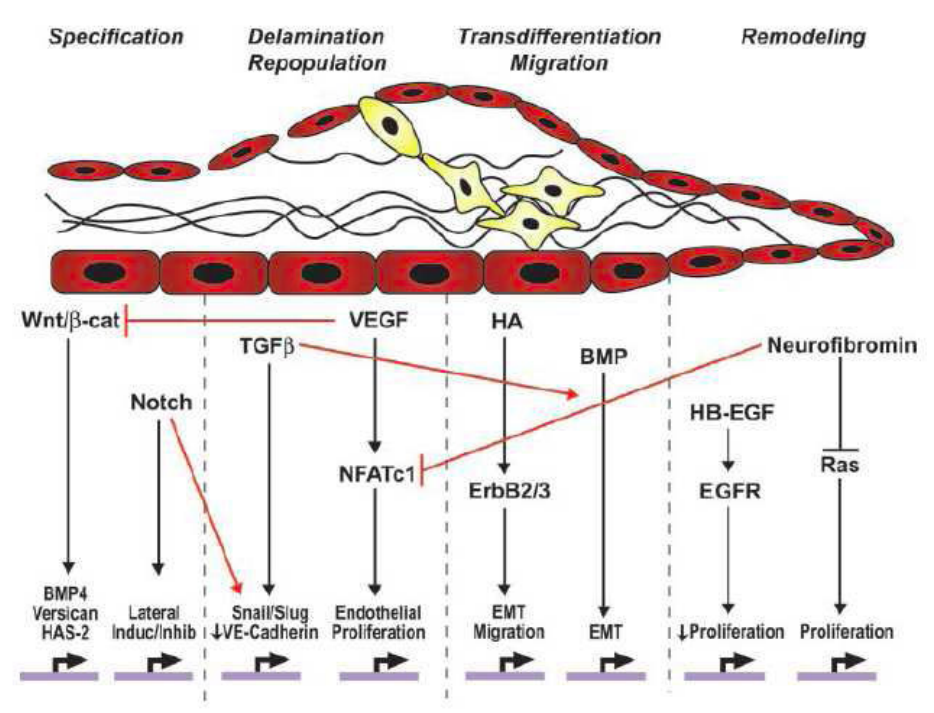

Figure 2. Valvulogenesis signalling complexity as proposed by Armstrong EJ and Bischoff J. From [147] 
The pleiotropic factor VEGF is considered a specific mediator in EMT, favouring endothelial cell proliferation. Downstream of VEGF, the transcriptional factor NFATc1 has intranuclear expression: this is limited to the endocardium not activated in the EMT process during the temporal window of cushion development, while it is expressed by some valve endothelial cells in the post-natal life, leading to hypothesize their participation in the repopulation of the adult endothelium. Even RANKL (receptor activator of nuclear factor $\kappa B$ ligand) exercises a control role on NFATc1, by inhibiting VEGF-induced cell proliferation when the endocardial cushion is more mature [148]. Upstream of NFATc1, two elements, connexins and DSCR1 (Down Syndrome Critical Region 1) play their function via signalling pathways associated to calcium cellular gradients. In cardiomyocytes, DSCR1 seems to be overexpressed during the increase of the cytosolic calcium and acts as modulator of the calcineurin dephosphorilating activity on NFATc1, by preventing its translocation to the nucleus. Connexin 45-composed gap junctions might allow the calcium extracellular diffusion in the endocardial cushions after the VEGF-mediated activation of the calcium transients in endothelial subpopulations[147].

The transcriptional factor Notch1 rules osteogenic differentiation as well as valve development: its signalling in the endocardium might induce an increase of TGF- $\beta 2$ expression in the myocardium, able to trigger EMT in endocardial cells through the cytosolic activation of Snail and Smad [149]. Activators of the TGF- $\beta$ transduction pathway are even the bone morphogenetic proteins (BMPs), in particular BMP2, which causes powerful induction of Smad6 in the cusp endothelium $[150,151]$.

During EMT, PECAM down-regulation in endothelial cells is followed by smooth muscle actin hyper-regulation: Wnt/ $\beta$-catenin pathway can be hence considered a link in between the mesenchymal activation and the populating process of the cardiac jelly with mesenchymal cells.

Beside these transduction pathways, it is equally important the integration of extracellular matrix signals, so called matrikines. ErbB proteins are involved in cell proliferation of cardiac cushions and their signalling is mediated by hyaluronic acid (HA), a highly hydrophilic glycosaminoglycan, which is able to extend the extracellular space and controls the ligand availability [147]. For both development and maintenance of mesenchymal cells in the valve leaflet, Sox9 is necessary by favouring cell proliferation and ECM correct alignment [152]. Recently, it has been recognized to the epicardium cell-secreted protein periostin a particular importance during the atrioventricular valve development in promoting differentiation of epicardial stem cells [153, 154].

New high-speed fluorescence microscopic technologies have allowed verifying the large interplay of different pathways in the development of the cusps and especially, they enabled a better understanding of the first events in valvulogenesis, arguing in favour of an invagination rather than a formation of endocardial cushions [155].

Recent gene expression studies revealed an up-regulation for $\alpha$-SMA, Snail and $\beta$-catenin as well as acetyltransferase p300 (ATp300). Indeed, microRNA analysis identified a specific role for miR-125b in the down-regulation of p53 [156]. 
Growth factors involved in embryonic development have been incorporated as widely contemplated strategy in bone and joint regenerative medicine. In the heart valve field, this approach has not been frequently applied [157], until now preferring in vitro comparative investigations on cell stimulation with sole growth factors, as TGF-beta, VEGF and BMPs $[158,159]$.

\subsubsection{EMT-inducing biomaterials}

Heart valve development is a complex process where signalling molecules and specific extracellular matrix elements interact. In response to these several stimuli, endocardial and epicardial cells adhere to the surface of the cardiac cushions and start an endothelial-tomesenchymal transition (EMT), leading to the formation of an elongated cusp structure [138].

The initial phase of valve formation depends on many extracellular matrix proteins [160]. The highly hydrophilic glycosaminoglycan HA is the major component of the endocardial cushions and its content is also elevated in the adult spongiosa layer, guaranteeing appeasement from the shocks provoked by the enormous pressure variations during the cardiac cycle. When seeded in vitro with VICs, hydrogels at various HA percentage have demonstrated to modulate ECM synthesis and induce also the production of elastin [161, 162].

Composite scaffolds of collagen and elastin have shown to reproduce the anisotropic spatial distribution of aortic ECM fibres and hence possess the potential to create heart valve replacements with a native-like microenvironment [163]. Mechanical strength properties of collagen have also been previously exploited in combination with HA, thus obtaining a cell-bioactive ECM milieu [164].

\subsection{Biocompatibility indications}

\subsubsection{Biomimetic strategies}

Functional endothelium together to resistant and flexible mechanical performance, mainly ensured by collagen and elastin, are critical components in the early clinical patency of a viable valve substitute. Starter matrices both for TEHV and TGRHV approaches should possess attractive properties towards cell elements facilitating their adhesion, penetration and further maturation. Most decellularized heart valves retain an intact basal membrane lamina, which represent the ideal microenvironment for endothelial cell attachment and spreading. This socalled contact guidance takes advantage of the specific nanotopography of the heart valve intimal ECM to increase cell bioaffinity. In order to recreate a valve-like microenvironment, surface functionalization with peptides, as laminin-extracted YIGSR (Tyr-Ile-Gly-Ser-Arg), selectively enhances endothelial cell adhesion and proliferation without thrombogenic effects [165]. Protein pre-coating of valve scaffolds with fibronectin or elastin-derived VAPG (ValAla-Pro-Gly) can enhance cell engrafting and differentiation [25, 80]. Self-assembling peptides containing YIGSR or VAPG create nanomatrix milieu mimicking the endothelium and resulting in increased endothelialisation and proliferation of vSMCs [166]. 
RGD and GRGDSP are both functional domains belonging to fibronectin. Stent biofunctionalisation with these cell adhesive ligands has been reported to result in controversial issues: while promoting endothelial cell adhesion and coverage, it favours platelet attachment [167-169]. Thus, the usage of these adhesive sequences should be cautious in perspective of thrombotic events.

Positive cell-affinity effects can be instead obtained by coating scaffold surfaces with fibrin, which however can be employed only as coating solution lacking of important mechanical assets [170, 171].

Particularly appealing is the application of peptides selected by phage display. This technology offers the possibility to create combinatorial peptide libraries, where still unknown cell recognition surface molecules can be discovered. A new peptide ligand, i.e. TPS, was identified through cell-SELEX system (Systematic Evolution of Ligands by EXponential enrichment) and covalently linked to methacrylic polymeric matrix to selectively capture endothelial cells [172].

In combination with natural materials, new matrices based on silk and chitosan, a polysaccharide found in Crustaceans, could consent the accomplishment of hybrid valve scaffolds, where endothelial cells can better adhere and proliferate [173].

\subsubsection{Antimicrobial treatments}

Although no infections have been recorded yet after implantation of porcine- or bovinederived tissues, the risk of transmission of porcine retroviruses or Creutzfeldt-Jacob disease has not to be underestimated. In order to avoid new trans-species viral combinations, endonuclease treatments generally applied after decellularization could be therefore preventing in this sense. The use of foetal bovine serum in heart valve tissue engineering and cryopreservation is also controversial and its substitution with serum replacement should be introduced in good manufacture practice.

The first infective risk is primarily represented by bacterial/fungal contamination. Current antimicrobial treatments are based on cocktails of large spectrum antibiotics and antimycotics and are performed on decellularized scaffolds prior to further in vitro cell seeding or in vivo implantation. Synthetic biomaterials are mostly submitted to gaseous disinfection with plasma gas or ethylene oxide.

While UV rays have a low penetration power for disinfection, gamma-irradiation is effective in abrogating contaminations. However, even when combined with the radioprotective cryopreservant DMSO, it is able to induce deep damages on the ECM fibres with deleterious effects in the long-term performance of so-treated heart valve substitutes [174].

\subsubsection{Cues for thrombosis and neointimal hyperplasia prevention}

Scaffold modifications for antithrombogenicity have been developed using endothelial coverage, ECM peptides inducing endothelium formation or by engineering their surface with inhibitors of platelet function or anticoagulant agents [175]. 
As already discussed, a normal endothelium is protective from platelet adhesion and aggregation in the first phases after implantation. Achievable in vitro with endothelial cells and their circulating progenitors, endothelialisation has to occur on all surfaces contacting blood, otherwise uncovered regions can be platelet-attractive. The implementation of extracellular matrix with endothelial adhesive ligands, as YIGSR, can foster a complete endothelial coverage [165].

Other cell sources for non-thrombogenic surfaces are represented by MSCs, which offer high compatibility with blood cells and are lacking of the platelet selective surface ligand HSPG [176].

Besides its EC and SMC affinity, HA, similarly to other GAGs, is effective in the prevention of platelet adhesion [177].

Other molecules able to inhibit thrombotic formations are phosphorylcholine phospholipid and polyethylene glycol, which counteract the adsorption of serum proteins $[178,179]$.

Instead of its preventive blockage, protein adsorption can be opportunely manipulated with fibrinogen to circumvent further diffusion of other serum molecules: while some hydrophobic domains of the molecule are adsorbed, others are exposed creating fibrous conformations able to attract endothelial cells [180].

Nitric oxide (NO), a chemical compound normally produced by functional endothelial cells and owning antithrombogenic efficacy can be also derived from decomposition of diazeniumdiolates. The incorporation of these molecules in scaffolds is able to drastically reduce in vivo thrombi formation $[165,181]$. NO performs a second function in preventing valve complications. In fact, it is able to directly down-regulate proliferation pathways in vSMCs, thus precluding neointimal hyperplasia $[182,183]$. Upon NO treatment, the activity of the protein synthesis machinery is reduced in these cells, observing a drastic reduction in the production of collagen [182]. Local delivery of stable S-nitrosothiol groups, incorporated in different compounds of serum albumin, has demonstrated to significantly reduce both platelet aggregation and neointimal proliferation in animal models of vascular injury [184]. Other NO formulations were identified to ensure a sustained and controlled release of the endothelialderived molecule. When applied to VICs from the porcine aortic valve, combinations of poly(Llactic acid) (PLLA) matrix systems incorporating NO-delivering poly(lactic-co-glycolic acid) (PLGA) nanoparticles reduced intercellular adhesion molecule 1 signalling and increased cyclic guanosine monophosphate levels, demonstrating therefore NO antiinflammatory and anticalcific potentialities [185].

Among anticoagulants, heparin is the most employed drug in the clinical activity. Resembling the glycosaminoglycan heparin sulphate in its chemical composition, it exerts blocking effect on the coagulation cascade also when immobilized into a scaffold. However, its pharmaceutical validity in this setting is not so good as in its soluble form [186].

Limited activity shown by immobilized heparin is surpassed by hyrudin scaffold incorporation. When conjugated to several biomaterials, this chemical agent is able both in vitro and in vivo to quench thrombin and prevent its further activity [187, 188]. 
Neointimal hyperplasia represents another complication in the in vivo performance of new viable valve substitutes. Besides $\mathrm{NO}$, other chemical agents are currently used to counteract vSMC proliferation at the basis of neointima development. Local delivery of growth factors involved in the apoptotic pathways of vSMCs has been reported to attenuate the phenomenon with efficiency extents depending on the local concentration of the cytokine at the injury site $[190,191]$. In lieu of locally delivering specific growth factors, the oral administration of drugs stimulating their cell production could represent a more compliant therapy for treated patients [192].

Other blocking strategies have been developed by directly targeting oligonucleotides or receptor molecules involved in vSMC proliferation. The use of antisense strategies or humanized monoclonal antibodies contributes to abolish the expression of proteins needed for cell cycling [193-195].

As for the administration of growth factors, these approaches rely on a non-functional endothelium and on the local vector availability.

Nevertheless, even if not yet tested in other formulations than soluble particles, growth factorand antisense-based approaches could show promising potential when incorporated in scaffolds for cardiovascular applications.

More specifically tackling tactics can be exercised throughout the usage of viral particles with vascular tropism. Attenuated herpes simplex virus 1 , obtained by removing only $\gamma_{1} 34.5$ genes, originally demonstrated its efficacy in malignant cancer therapies. Indeed, its ability to infect dividing cells can be used together with its tropism to vSMCs as efficient antiproliferative agent. In particular, while showing no systemic toxicity and a persistent activity for at least 4 weeks, its infective state can be electively blocked by antiviral drugs [196].

TGF-beta 1 and PDGF-BB pathways are up-regulated in the genesis of intimal hyperplasia. These growth factors contribute to the recruitment of adventitial cells by neighbouring medial SMCs through a paracrine mechanism and are, therefore, perfect targets in a blockade strategy. Cell-selective adenoviral gene transfer of Smad7 or PDGF-beta receptor reduced adventitial cell migration and vascular remodelling after balloon injury [197, 198].

Notwithstanding the efficiency and the possibility of control related to these systems, the use of viral agents is still accompanied by ethical and safety concerns, which argue in favour of other therapeutic strategies.

Already evaluated in combination to biomaterials is another drug class, which has been firstly applied in the immunotransplantation field. Limus derivatives are a large family of compounds preventing either allograft rejections or restenosis after angioplasty. Conversely, systemic toxic effects, unspecific antiproliferation activity on ECs and SMCs, and variable efficacy associated with their usage in vitro or in vivo are at the basis of the reported controversial results [199-203]. 


\subsubsection{Functionalization of decellularized extracellular matrices}

While decellularized ECMs have demonstrated the ability of in vivo self-regeneration, their structural and functional properties can be improved by conditioning with synthetic biomaterials. The advantage of such strategies resides in the combination of uniform and mouldable artificial products with bioactive natural scaffolds. Nanotechnology approaches are currently under investigation for the stable introduction of adhesive sequences or for the entrapment of structure-mouldable peptides (unpublished data).

\subsection{5.. Anticalcification approaches}

From the observation of the pathological events occurring in vessel/valve deterioration, different anticalcification strategies have been developed. In the bioprosthetic valves, mineralization is strictly related to the presence of phospholipids (phosphatidil serine and phosphaditil choline) and phosphate backbone of degraded nucleic acids in the extracellular milieu of a no more vital tissue [204,205]. These extracellular phosphate groups are perfect nucleation sources for mineral deposition. The progression and entity of calcification is dependent on many factors and surely, the lack of a cell-favoured homeostatic pathway, provoked by glutaraldehyde (GA) cytotoxicity, can be useful to accelerate the phenomenon of diffuse mineralization on ECM fibres.

A reduction in the mineral deposition has been attempted through addition of several GAdetoxifying approaches. Challenged alone with valvular cells or cross-linked to GA-fixed bioprostheses in simulated body fluid, procyanidines have demonstrated cell biocompatibility, dose-dependent inhibition of alkaline phosphatase cellular activity and consequently, of matrix mineralization [206].

Lipid extraction for the removal of cell membrane phospholipids has been pursued by applying solvents or detergents with special attention to the preservation of ECM fibres. In an in vivo model, the long chain aliphatic alcohol octanediol in $40 \%$ concentration has proven to be an efficient anticalcification agent for GA-treated bovine pericardium [207].

A more diluted octanediol is in the organic solvent used as buffer for genypin/glutaraldehyde fixation of bovine pericardial tissues, previously submitted to sodium dodecyl sulphate decellularization and/or successively treated with several amino acids or sodium bisulphite. In respect to GA-fixed samples, all these different genypin-based variants turned out in in decreased calcium/phosphorus content and conserved tissue stability by resistance to pronase enzymatic degradation [208]. However, despite the concomitant evaluation of decellularization, which could have partaken in the removal of alpha-gal epitopes, the levels of these xenoantigens were valuated only between genipin/GA- versus sole GAfixations particularly [208].

Ethanol cross-linked to triglycidyl amine is also able to reduce GA-associated calcification both in rat subdermal and sheep models, however it is responsible of structural instability in treated tissues [209]. In another study by Sacks et al, triglycidyl epoxy-crosslinking without GA addition demonstrated improved biomechanics in respect to GA alone [210]. 
Amino acids, as glycine, phenylalanine or aspartic acid, are largely employed in anticalcification processes to potentiate the action of alcohols and metallocene dichlorides [211].

Detergent application, at the basis of most decellularizing techniques, exploits tensioactivity to eliminate membrane lipids, indistinctly from the presence of phosphate groups. Treatments with Triton X100 and sodium cholate, deoxycholic acid, N-lauroyl sarcosinate or sodium dodecyl sulphate, especially if combined with DNA/RNA nucleases, resulted in no calcific events both in vitro, in preclinical animal models and/or in the clinical stage [25-28, 102, 212].

Calcium and phosphorus signalling has been tackled via calcimimetics and biphoshonates by directly acting on calcifying cells. So far evaluated mainly in the renal district, calcimimetics, as R-568 and AMG 641, could in the future be incorporated in synthetic and natural matrices to selectively block parathyroid hormone pathway responsible for renal artery calcification [213]. Interestingly, another calcimimetic, cinacalcet, has been reported to reduce vascular calcification in the renal aorta of uremic rats in association with further encouraging outcomes on vascular remodelling and myocardial fibrosis [214].

Testified as possible medical therapy for calcific aortic stenosis, bisphosphonate molecules incorporated into polyurethane scaffolds induced resistance from calcification in 60 day-long rat subdermal tests and in 90 day-long evaluation in the circulation as pulmonary valve cusp [215].

\subsection{In vitro and in vivo novel tissue technologies}

\subsubsection{Bio-electrospray}

Further advances in cardiovascular regenerative medicine have recently been introduced to ease the achievement of intraoperative tissue-engineered organ units: bioelectrospray is emerging as a powerful tool both for the creation of specific nanotopographic surface and for homogeneous/spatial cell seeding or coating of valve scaffolds [216, 217].

\subsubsection{Monoclonal antibodies and DNA aptamers}

Monoclonal antibodies can be applied to selectively capture cell populations expressing specific cluster differentiation molecules: an increase in the attachment of endothelial or mesenchymal stem cells was achieved by coating scaffold surface with anti-CD34, anti-CD90 or anti-CD133 [218-220].

Aptamers, 70-90 nucleotide-long single strand oligos, can bind to specific molecules with high selectivity and affinity. Identified through combinatorial phage display technology, they were immobilized on the surface of polydimethylsiloxan or polytetrafluoroethylene patches precoated with the antithrombogenic PEG. The scaffold formulation was able to block serum protein adsorption and selectively recruit EPCs from the bloodstream [221]. EPC-attracting aptamer technology has also been applied with similar results in valve scaffolds [222]. 


\subsubsection{Organ printing}

Extremely fascinating in bioengineering is the possibility to fabricate complex living structures by organ printing. This approach contemplates different sequential steps for the realization of biological tissue and organ substitutes: computer-aided design (CAD), image processing, modelling with solids, free-form fabrication, designing, simulation and finally manufacturing [223]. Several applications of this technology have been proposed since 2001 [224] and are currently focusing also in the preparation of cardiovascular tissues [225, 226]. Until now, organ printing has been rendered useful in the heart valve field not for biofabrication, but for preoperative planning and valve replacement simulation in complex interventions [227].

\subsubsection{In body tissue architecture}

Actually, the concept of in body tissue architecture finds limited exploitation in the development of heart valves substitutes. Interestingly, the Japanese group of Nakayama et al. has produced a trileaflet valved-shaped construct based on this technology. As in the case of Campbell et al. [87], the approach takes advantage of the normal biological response to a foreign material developed by the body, implanting silicon rods in the subcutaneous tissues. In a period of 4 weeks, these grafts are first 'embedded' by granulation-like tissue, then removed and fused each other for correct valvular shaping and reinserted to complete the cell covering. At the end of the process, the particular arrangement given by the researchers allows eliminating supporting artificial materials to attain a trileaflet valve conduit [228].

\subsection{Implantation techniques: Classical cardio-surgical implant versus transapical and TAVI access}

Open chest interventions have represented the main surgical modality for diseased heart valve treatment. The classic cardio-surgical implant generally implies median sternotomy and cardio-pulmonary bypass with cannulation of both venae cavae and aorta in hypothermic conditions. This technique is largely used for the implantation of bioengineered valves in animal model testing or in clinical valve substitutions [93].

Classic cardio-surgical valve substitution is for sure a life-saving procedure. However, its invasiveness results in infective risk and pain in the immediate post-intervention period. Additionally, in children the current lack for valve substitutes with somatic adaptation ability submits these paediatric patients to several re-do procedures until their adulthood.

Owing to the improvement in life expectancy, the elderly represent another cardiopathic population in need for re-intervention.

Catheter-assisted techniques are minimally invasive implantation approaches, experimented in animal models in 1965 and in humans in 2000 [229, 230]. The percutaneous trans-catheter implantation of an aortic valve prosthesis (TAVI) was firstly performed by Cribier et al. some years later [231]. In a TAVI device, a bioprosthetic aortic valve is mounted on an expandable stainless steel stent. It is then compressed to nearly one-third of its diameter through a crimping procedure and introduced in a catheter before its implantation in the patient. Once the correct position has been assessed by fluoroscopy imaging, the crimped valve is balloon- or self- 
expanded and tightly juxtaposed to the insufficient aortic valve. The procedure of transcatheter aortic valve insertion in degenerated surgically implanted bioprostheses is particularly indicated for high surgical risk patients, since a minimal thoracotomy access is required instead of sternotomy and cardio-pulmonary bypass.

Through a catheter-assisted system, tissue-engineered heart valves were transapically implanted in sheep and non-human primates as pulmonary valve replacements following a minithoracotomy $[95,232]$. Although performing during 2 month-long experimental evaluation, cusp thickening was reported in these poly-4-hydroxybutyrate coated nonwoven polyglycolic acid-based TEHVs [233].

A similar transapical approach was adopted by the same group for TEHV implantation in sheep systemic circulation. Haemodinamically evaluated up to 2 weeks, these tissueengineered aortic replacements were found post-mortem in active remodelling, with merely collagen/GAG ECM synthesis and freedom from thrombotic formations or structural degenerations [97].

These intriguing experimental evidences demonstrate the feasibility of such an approach also for bioengineered valve substitutes. In addition, a transapically-delivered bioengineered TAVI could be a particularly beneficial option for patients with severe aortic valve calcification.

However, crimping/re-opening effects on cell survival, ECM microstructure and valve function should be further examined both in vitro and in vivo within a longer observational time. Decellularized scaffold-relying approaches could be especially influenced by this mounting-related shock with immediate and significant consequences on tissue hydration, GAG content and collagen/elastin fibre interplay.

\subsection{Imaging tools}

\subsubsection{Two Photon-laser scanning confocal microscopy}

More and more advanced optical visualization systems are offering sophisticated functions for non-invasive deeper penetration and dynamic evaluation of developing organs and bioengineered constructs. Cell adhesion and spreading in thick 3D structures can now be analysed until almost millimetre depth by means of 2 photon-laser scanning confocal microscopy (2P-LSCM). Differently from more common linear-based imaging, 2P-LSCM exploits the simultaneous adsorption of two near IR-photons to excite endogenous fluorophores, as tricarboxylic triamipiridinium elastin-derivates, without previous sectioning or staining. Besides elastin networks, it is possible to study collagen fibres through second harmonic generation in an adsorption-free process [234]. This unique imaging modality offers the unquestionable possibility to dynamically monitor relatively small living tissues without manipulation artefacts [235].

\subsection{2. $M R I$}

Another non-invasive imaging modality is magnetic resonance: widely applied in the clinical setting, it surpasses ionizing radiation-based echocardiography for the optimal spatio- 
temporal resolution [236]. In vivo performance of bioengineered heart valves can be constantly monitored by MRI with the feasibility of precise dimensional measurements [229, 237]. Cell passive loading of magnetic resonance nanoparticles in vitro allows for their dynamic tracing in implanted tissue-engineered constructs. Formulated in different diameter size (10-1.000 $\mathrm{nm}$ ), most used MR nanoparticles, i.e. $50 \mathrm{~nm}$-diameter superparamagnetic iron oxide (SPIO) ones, are cell-incorporated by endocytotic loading or up-taken in enhanced way by combination with protamine sulphate. Cell survival, motility and differentiation abilities have been reported to be not strongly influenced by SPIOs, thus perturbing mainly the magnetic field in the populated tissue [238].

\subsection{3. $\mu O C T, P E T$ and SPECT}

While MR technology allows qualitative and quantitative dynamic functional studies, detailed information on valve degeneration can be attained by means of tomography-based imaging [239]. With its 1- $\mu$ m-axial resolution, micro-optical coherence tomography ( $\mu \mathrm{OCT}$ ) would be a particularly interesting tool in in bioengineering to elucidate cellular and subcellular events in the early tissue engraftment as well as in the initial onset of valve disease [240].

Positron emission and single photon emission computed tomography (respectively PET and SPECT) possess an inferior spatial resolution. As SPIOs, radionuclide-labelled cells can be obtained by means of passive loading. Cell tracking, however, will be strictly limited by the radioisotope half-life: among the commonly used radionuclides, the SPECT probe ${ }^{111}$ In-Oxine has the longest detectable radioactivity of 2.8 days. Another limitation associated with SPECT is the necessity to load a relatively high amount of radioisotopes for quantitative evaluations, at the expense of cell viability. The more sensitive PET suffers instead of the shorter half-life of used probes [241]. On this account, PET and SPECT are not ideal to evaluate in vivo mid/ long-term dynamic remodelling of bioengineered valves, but necessary to identify calcific degenerations [28].

\subsection{Heart valve tissue banks}

After the production of new valve substitutes, their storage and further capillary distribution are essential steps to the prompt realization of interventional therapies.

Off-the-shelf solutions must rely on appropriate conservation procedures, avoiding the use of cytotoxic fixatives able to compromise further in vivo remodelling/regeneration of TEHVs and TGRHVs.

Cryopreservation has been established as alternative storage technique to GA-fixation, when allografts started to be employed in clinic 50 years ago. Initially called homografts, pulmonary valves from cadaveric donors found large usage in the Ross procedure instead of the patient's own valve, eterotopically transposed for the replacement of the degenerated aortic root [242]. After isolation, donor tissues are examined to exclude lacerations and/or unsuitability sources and graded following macroscopic qualitative evaluation. Antimicrobial procedures are then performed to eliminate bacterial and fungal infective risks with constant control for effective microbe removal $[243,244]$. Decontaminated tissues are immersed in cryopreserving solutions, 
usually based on cell culture medium added with a low percentage of the cryoprotectant dimethyl sulfoxide (DMSO). DMSO contributes to reduce hyperosmolarity shocks and ice crystal formation, which would induce deleterious effects on heart valve structure and mechanics. Tissues, introduced in highly resistant package, are then submitted to time- and condition-controlled cryofreezing and stored in vapour-phase nitrogen tanks for a maximum 5 years long period if unused.

On a constantly updated survey of the European Homograft Bank, nearly 4.500 cryopreserved valves on about 5.200 selected tissues were employed for complex valve malformations in children, women of child-bearing age with diseased cardiac valves, patients with anticoagulation contra-indication or patients with severe endocarditis [245].

While undoubtedly more immunotolerable than xenogeneic bioprostheses, their performance in the patients has a comparable endurance. Causes for this restricted durability have been firstly searched in the survival of populating cell elements. Strips of aortic valve cusps and walls were stimulated with vasoactive concentrations of potassium, 5-hydroxytryptamine, noradrenaline, endothelin-1 and prostaglandin F-(2alpha) to test cell contractility after cryopreservation: no significant differences were observed in comparison to fresh tissues [246]. Apoptotic studies revealed cell necrosis, related to ischemia rather than a cryopreservationdependent activation of death program [247]. Indeed, albeit its cryoprotective action, DMSO is cytotoxic at physiologic temperature and could be responsible for cell death in unwell washed out thawed valves [248]. In addition, ultrastructural damage was reported as major source of scarce ECM stability.

Cryopreservation technique has already been tested as possible storage modality of tissueengineered or in vivo regenerating decellularized valve substitutes: independent deep imaging analyses revealed however contrasting observations upon this treatment. Evaluations with transmission electron microscopy of cryopreserved/decellularized specimens found typical ECM pattern with no collagen swelling/shrinkage or clearly distorted/disrupted elastin fibres [25]. Two photon-laser scanning confocal microscopy on decellularized/cryopreserved valves demonstrated structural integrity of ECM fibres [249]. Cryopreservation detrimental effects were instead reported with the application of the same imaging technology by SchenkeLayland et al. [250]. The same group proposed vitrification as ECM preserving alternative to cryopreservation. Vitrification, defined by the Authors as 'ice-free cryopreservation', mainly differs from the standard method for the additional use of formamide and 1,2-propanediol. Vitrified porcine pulmonary valves showed better haemodynamic and biologic performance in comparison to cryopreserved tissues [251]. However, chemical compounds added to the cryopreserving medium could negatively affect cell viability.

\subsection{Inflammation in heart valve regenerative medicine}

\subsubsection{Adverse effects of inflammation on cardiovascular tissue engineering/regeneration}

The natural response of a body to an implanted tissue develops similarly to the healing process of a wound and analogously resolves at the graft acceptance. The implant is initially surrounded and infiltrated by a granulation tissue rich in inflammatory mononucleated cells, as 
monocytes and neutrophils acquiring in situ a mature, active phenotype. Debris removal and cytokine release, operated by macrophages, contribute to activate the last remodelling phases, depending on recruited fibroblasts and smooth muscle cells. A delicate balancing is involved in this rejecting/engrafting process. An intensification in the pro-inflammatory macrophage function, related to a not fully biocompatible synthetic or natural scaffold, provokes the onset of immunologic responses by enrolling further cells, as lymphocytes.

A related aspect is also the genesis of firstly cell calcification and hence extended ECM mineralization. Remained into incompletely decellularized tissues (especially of xenogeneic origin) or fruit of cell death activation (necrosis or apoptosis) in tissue-engineered constructs, cellular debris can, in fact, trigger inflammatory and/or immunologic response activation. Comparably to foam cells in atherosclerotic lesions, cell death of foreign body giant cells, i.e. fused collections of macrophages, generates apoptotic bodies. These latter, together to the similar ones or to the debris both released by dying construct cells, further propagate inflammation and generate a suitable microenvironment for calcium nucleation [252-254].

As previously mentioned, retention of xenoantigens and detergents could further increase the in vivo pro-inflammatory potential of decellularized matrix-based approaches [255]. Nevertheless, some unsuccessful results described for both TEHVs and TGRHVs, trusting on decellularized tissues, could hypothetically reside in the decellularization-induced exposure of previously masked epitopes or even in ECM micro-modifications, recognized as non-self by the immune system. A recent paper by Zhou and coll. discussed upon the effects of different decellularizing treatments on ECM preservation, thrombogenicity and immunogenicity, by in vitro direct human blood contact. While sodium deoxycholate-based decellularization induced no ECM disruption and complete decellularization, for all proposed methods, including sodium dodecyl sulphate, trypsin/EDTA or trypsin-detergent-nuclease, thrombotic and immunological responses were surely higher than those in glutaraldehyde-fixed specimens [256]. A confirmation about these findings is supported by another work published in the same year: through a quantitative approach based on immunoblotting technique, Arai and Orton were able to demonstrate the detection of soluble protein antigens still maintained in bovine pericardium and porcine heart valves after decellularization with sodium dodecyl sulphate and sodium deoxycholate [257].

The treatment based on Triton X100, sodium cholate and endonucleases, not evaluated in the previously cited studies, demonstrated to produce acellular heart valve substitutes, evoking in vivo null thrombogenic or inflammatory/immunogenic responses thanks to the complete alpha-gal elimination [26, 27, 135, 136].

So far, endothelialisation strategies represent - also in the clinical setting - the almost unique modalities to prevent thrombogenicity-related excessive inflammation in tissue-engineered heart valves approaches, especially when autologous endothelial cells are employed [93].

\subsubsection{Favourable inflammatory events on cardiovascular tissue engineering/regeneration}

Differently from any other cardiovascular tissue, as the adjacent myocardium and arterial wall, adult heart valve atrioventricular and semilunar leaflets possess a highly represented CD34- 
positive interstitial population (Figure 3), as also evidenced in the work of Barth and colleagues [258]. The presence of CD34-expressing cells in these tissues reminds on almost two possible and equally valuable hypotheses on the role of these cytotypes in these districts. CD34 is a glycoprotein expressed on endothelial cells and on their circulating progenitors (EPCs). It is also identifiable on the surface of bone marrow-residing haematopoietic stem cells, which are known to be myeloid cell precursors of EPCs and of other cells, among which monocytes and macrophages (their tissue-activated form) [259]. Other inflammatory cell markers have been found positive even in uncompromised cusps of young donor's valve allografts (Figure 3) [260]. In particular, CD68-expressing macrophages are widespread both in semilunar and atrioventricular valve tissues, without the intensely site-concentrated cell distribution usually observed in pathological specimens.
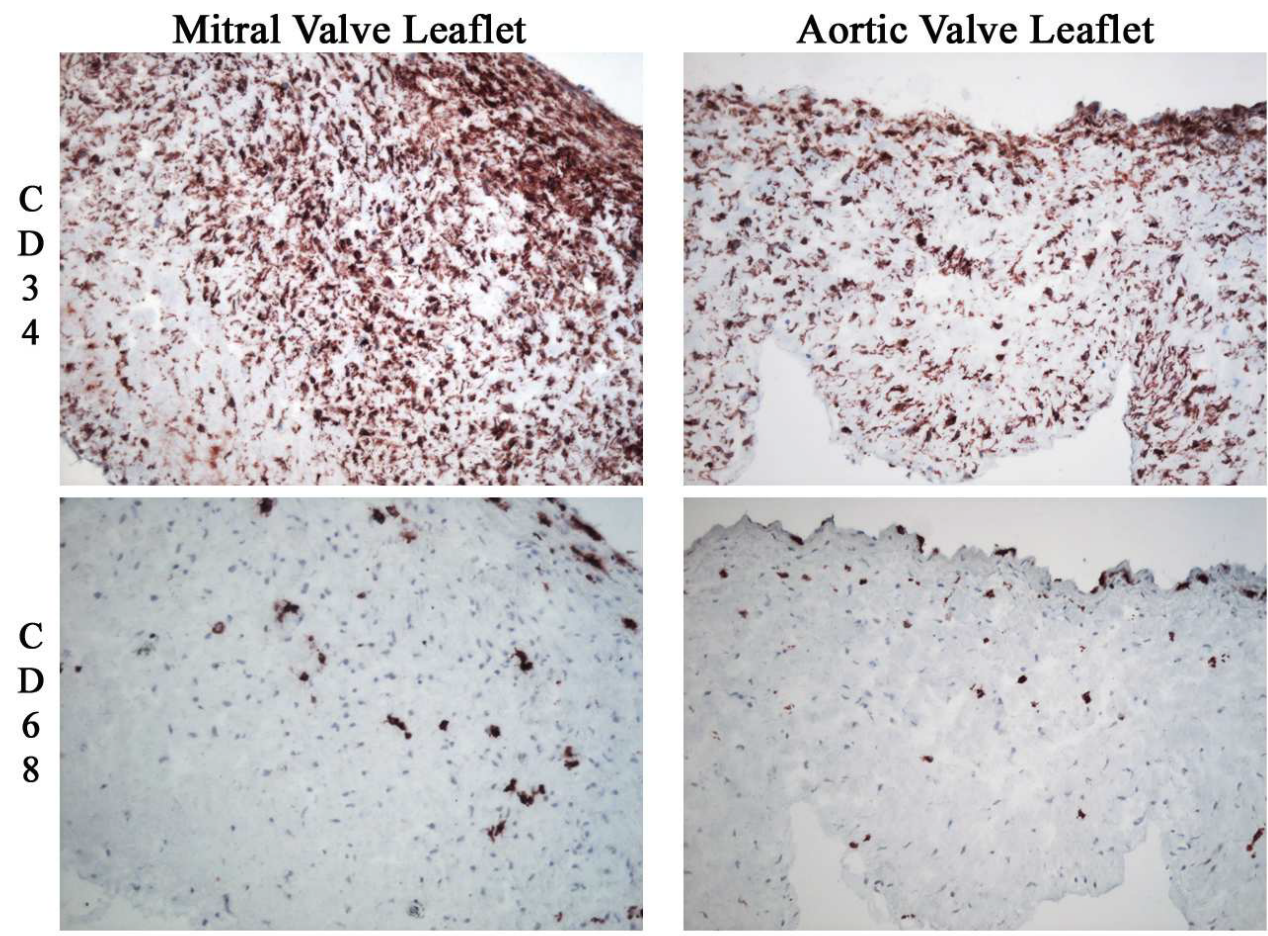

Figure 3. Hematopoietic cell markers expressed in the mitral and aortic valve leaflets of a 26 year-old donor allograft. CD34 is widely positive in all cusps tissues. CD68 expression is scattered and homogenously distributed in all leaflets, likely to identify a protective function, as that observable in the healthy myocardium. Magnification: 70x

The meaning of this presence in healthy tissues is not known, but it could be likely that the continuous mechanical stress imposed to the thin leaflets, together with the direct exposure to blood, needs a sentinel function exerted by macrophages and other cells. 
Another interesting hypothesis rises from the observation of the double nature of the macrophage cell. In effect, a phenotype committed to tissue regeneration has been discovered besides the typical protective tasks played by these cells. For the similarity to T2 helper lymphocytes, these macrophages have been named M2 and can be characterized by the expression of interleukin-10 (IL-10) and mannose receptor (MR) [261]. In the analysed valve specimens, the immunodetection of CD68, a broad macrophage marker, is associated to the expression of MR and IL-10, as visible in Figure 4.
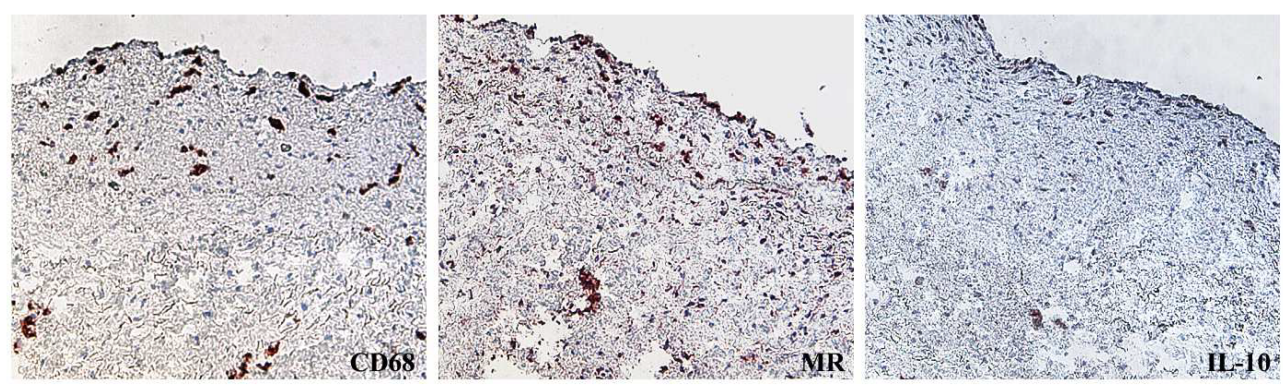

Figure 4. Evaluation of M2 macrophages in the mitral valve leaflet of a 26 year-old donor allograft. MR and IL-10 are likely to be expressed by the same CD68-positive cells. Magnification: 100x

This expression pattern of M2 macrophage typical markers is also preserved interspecies in mammals, further corroborating the notion of an evolutionarily conserved, constantly undergoing protection/regeneration process in the heart valve tissue. Porcine, bovine, sheep and non-human primate heart valves share, in fact, a similar cell distribution and localisation of CD68, MR and IL-10 markers (Figure 5).
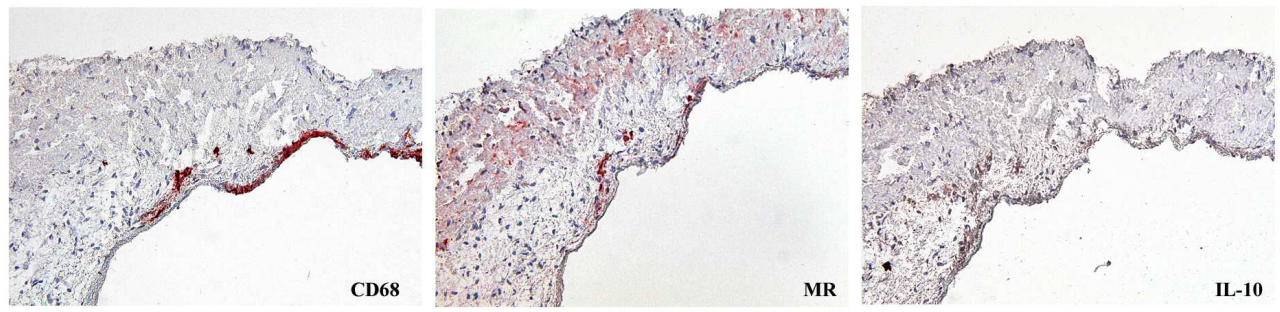

Figure 5. M2 macrophage pattern in the aortic valve leaflet of a Macaca fascicularis subject. Magnification: 50x

As further supportive remark, the extensive identification of stem cells with diverse lineages in heart valves evidences the unique regenerative properties endowed by these tissues [260].

Type 2 macrophages have been additionally found in the early post-implantation phases of bioengineered valve replacements and reported to remain in the implanted tissues until the construct scaffold has been completely replaced by an autologous matrix [262]. 
The engraftment of differently attainable biocompatible TEHVs and TGRHVs could be facilitated with the modulation of the M1/M2 ratio in favour of the second player: as often verified for other cardiovascular tissues [263], inflammatory responses could be mitigated through specific pharmaceutical treatments. While still at the sunrise of a possible clinical application in cardiovascular disease treatments, RNA interference (RNAi) technology could be an attenuator of inflammation, thanks to the selective silencing of targeted genes. Scaffoldmediated therapeutic delivery of RNAi could enable localize treatment of inflammation without secondary systemic effects [264].

\section{Author details}

Laura Iop* and Gino Gerosa

*Address all correspondence to: laura.iop@unipd.it

Department of Cardiac, Thoracic and Vascular Sciences School of Medicine, University of Padua, Padua, Italy

\section{References}

[1] Wells FC and Crowe T. Leonardo da Vinci as a paradigm for modern clinical research. J Thorac Cardiovasc Surg 2004;127(4): 929-4

[2] Hufnagel CA. Surgery of acquired diseases of the cardiac valves. GP. 1953;7(2):69-81

[3] Starr A, Edwards ML. Mitral replacement: clinical experience with a ball-valve prosthesis. Ann Surg 1961;154: 726-40

[4] Langer R, Vacanti JP. Tissue engineering. Science 1993;260: 920-6

[5] Agrawal CM, Ray RB. Biodegradable polymeric scaffolds for musculoskeletal tissue engineering. J Biomed Mater Res 2001;55: 141-150

[6] Braunwald NS. Performance of materials in vascular prosthetic devices: heart valves. Bull N Y Acad Med 1972;48(2): 357-61

[7] Wisman CB, Pierce WS, Donachy JH, Pae WE, Myers JL, Prophet GA. A polyurethane trileaflet cardiac valve prosthesis: in vitro and in vivo studies. Trans Am Soc Artif Intern Organs 1982;28: 164-8

[8] Bernacca GM, O'Connor B, Williams DF, Wheatley DJ. Hydrodynamic function of polyurethane prosthetic heart valves: influences of Young's modulus and leaflet thickness.Biomaterials2002;23(1): 45-50 
[9] Kolff WJ, Yu LS. The return of elastomer valves. Ann Thorac Surg 1989;48(3 Suppl): S98-9

[10] Joshi RR, Frautschi JR, Phillips RE Jr, Levy RJ. Phosphonated polyurethanes that resist calcification.J Appl Biomater 1994;5(1): 65-77

[11] Rahmani B, Tzamtzis S, Ghanbari H, Burriesci G, Seifalian AM. Manufacturing and hydrodynamic assessment of a novel aortic valve made of a new nanocomposite polymer. J Biomech2012;45(7): 1205-11

[12] Shinoka T, Breuer CK, Tanel RE, Zund G, Miura T, Ma PX, Langer R, Vacanti JP, Mayer JE. Tissue engineering heart valves: valve leaflet replacement study in a lamb model. Ann Thorac Surg 1995;60(Suppl. 3): S513-6

[13] Shinoka T, Ma PX, Shum-Tim D, Breuer CK, Cusick RA, Zund G, Langer R, Vacanti JP, Mayer JE. Tissue engineered heart valves. Autologous valve leaflet replacement study in a lamb model. Circulation 1996;94(Suppl.): II164-8

[14] Shinoka T, Shum-Tim D, Ma PX, Tanel RE, Isogai N, Langer R, Vacanti JP, Mayer JE. Creation of viable pulmonary artery autografts through tissue engineering. J Thorac Cardiovasc Surg 1998;115: 536-546

[15] Schmidt D, Stock UA, Hoerstrup SP. Tissue engineering of heart valves using decellularized xenogeneic or polymeric starter matrices. Philos Trans R Soc Lond B Biol Sci 2007;362(1484): 1505-12

[16] Hoerstrup SP, Sodian R, Daebritz S, Wang J, Bacha EA, Martin DP, Moran AM, Guleserian KJ, Sperling JS, Kaushal S, Vacanti JP, Schoen FJ, Mayer JE Jr. Functional living trileaflet heart valves grown in vitro. Circulation 2000;102: III44-49

[17] Hoerstrup SP, Cummings Mrcs I, Lachat M, Schoen FJ, Jenni R, Leschka S, Neuenschwander S, Schmidt D, Mol A, Günter C, Gössi M, Genoni M, Zund G. Functional growth in tissue-engineered living, vascular grafts: follow-up at 100 weeks in a large animal model. Circulation 2006;114(1 Suppl): I159-66

[18] Yin W, Gallocher S, Pinchuk L, Schoephoerster RT, Jesty J, Bluestein D. Flow-induced platelet activation in a St. Jude mechanical heart valve, a trileaflet polymeric heart valve, and a St. Jude tissue valve.Artif Organs 2005;29(10): 826-31

[19] Mohammadi H. Nanocomposite biomaterial mimicking aortic heart valve leaflet mechanical behaviour. Proc Inst Mech Eng H 2011;225(7): 718-22

[20] Koroleva A, Gittard S, Schlie S, Deiwick A, Jockenhoevel S, Chichkov B. Fabrication of fibrin scaffolds with controlled microscale architecture by a two-photon polymerization-micromolding technique.Biofabrication 2012;4(1): 015001

[21] Ghanbari H, Viatge H, Kidane AG, Burriesci G, Tavakoli M, Seifalian AM. Polymeric heart valves: new materials, emerging hopes.Trends Biotechnol 2009;27(6): 359-67

[22] Grauss RW, Hazekamp MG, Oppenhuizen F, van Munsteren CJ, Gittenberger-de Groot AC, De Ruiter MC. Histological evaluation of decellularised porcine aortic 
valves: matrix changes due to different decellularisation methods. Eur J Cardiothorac Surg 2005;27(4): 566-71

[23] Rieder E, Kasimir MT, Silberhumer G, Seebacher G, Wolner E, Simon P, Weigel G. Decellularization protocols of porcine heart valves differ importantly in efficiency of cell removal and susceptibility of the matrix to recellularization with human vascular cells. J Thorac Cardiovasc Surg 2004;127(2): 399-405

[24] Bertipaglia B, Ortolani F, Petrelli L, Gerosa G, Spina M, Pauletto P, Casarotto D, Marchini M, Sartore S. Cell characterization of porcine aortic valve and decellularized leaflets repopulated with aortic valve interstitial cells: the VESALIO Project (Vitalitate Exornatum Succedaneum Aorticum Labore Ingenioso Obtenibitur). Ann Thorac Surg 2003;75: 1274-1282

[25] Iop L, Renier V, Naso F, Piccoli M, Bonetti A, Gandaglia A, Pozzobon M, Paolin A, Ortolani F, Marchini M, Spina M, De Coppi P, Sartore S, Gerosa G. The influence of heart valve leaflet matrix characteristics on the interaction between human mesenchymal stem cells and decellularized scaffolds. Biomaterials 2009;30(25): 4104-16

[26] L, Gandaglia A, Bonetti A, Marchini M, Spina M, Basso C, Thiene G, Gerosa G. In vivo Spontaneous Tissue Regeneration Of Allogeneic Decellularized Aortic Valves. Conference Proceedings 5th Biennial Meeting of the Society for Heart Valve Disease (Joint meeting with Heart Valve Society of America) - Berlin, Germany, 27-30 June 2009

[27] Gallo M, Naso F, Poser H, Rossi A, Franci P, Bianco R, Micciolo M, Zanella F, Cucchini U, Aresu L, Buratto E, Busetto R, Spina M, Gandaglia A, Gerosa G. Physiological performance of a detergent decellularized heart valve implanted for 15 months in Vietnamese pigs: surgical procedure, follow-up, and explant inspection. Artif Organs 2012;36(6): E138-50

[28] Dohmen PM, Lembcke A, Holinski S, Kivelitz D, Braun JP, Pruss A, Konertz W. Midterm clinical results using a tissue-engineered pulmonary valve to reconstruct the right ventricular outflow tract during the Ross procedure. Ann Thorac Surg 2007;84(3): 729-36

[29] Yang M, Chen CZ, Wang XN, Zhu YB, Gu YJ. Favourable effects of the detergent and enzyme extraction method for preparing decellularized bovinepericardium scaffold for tissue engineered heart valves.J Biomed Mater Res B Appl Biomater 2009;91(1): 354-61

[30] Cigliano A, Gandaglia A, Lepedda AJ, Zinellu E, Naso F, Gastaldello A, Aguiari P, De Muro P, Gerosa G, Spina M, Formato M. Fine structure of glycosaminoglycans from fresh and decellularized porcine cardiac valves and pericardium.Biochem Res Int 2012;2012: 979351

[31] Kuschert GS, Coulin F, Power CA, Proudfoot AE, Hubbard RE, Hoogewerf AJ, Wells TN. Glycosaminoglycans interact selectively with chemokines and modulate receptor binding and cellular responses.Biochemistry 1999;38(39): 12959-68 
[32] Badylak SF, Freytes DO, Gilbert TW. Extracellular matrix as a biological scaffold material: Structure and function. Acta Biomater2009;5(1): 1-13

[33] Naso F, Gandaglia A, Formato M, Cigliano A, Lepedda AJ, Gerosa G, Spina M. Differential distribution of structural components and hydration in aortic and pulmonary heart valve conduits: Impact of detergent-based cell removal. Acta Biomater 2010;6(12): 4675-88

[34] Lau WL, Festing MH, Giachelli CM. Phosphate and vascular calcification: Emerging role of the sodium-dependent phosphate co-transporter PiT-1.Thromb Haemost 2010;104(3): 464-70

[35] Cebotari S, Tudorache I, Jaekel T, Hilfiker A, Dorfman S, Ternes W, Haverich A, Lichtenberg A. Detergent decellularization of heart valves for tissue engineering: toxicological effects of residual detergents on human endothelial cells.Artif Organs 2010;34(3): 206-10

[36] Bayrak A, Tyralla M, Ladhoff J, Schleicher M, Stock UA, Volk HD, Seifert M. Human immune responses to porcine xenogeneic matrices and their extracellular matrix constituents in vitro.Biomaterials 2010;31(14): 3793-803

[37] Schnell AM, Hoerstrup SP, Zund G, Kolb S, Sodian R, Visjager JF, Grunenfelder J, Suter A, Turina M. Optimal cell source for cardiovascular tissue engineering: venous vs. aortic human myofibroblasts. Thorac Cardiovasc Surg 2001;49(4): 221-5

[38] Zhu L, Williams WG, Bellhouse B, Pugh S, Rabinovitch M. Effective endothelialization of polyurethane surfaces. Response to shear stress and platelet adhesion. ASAIO Trans 1990;36(4): 811-6

[39] Bengtsson LA, Phillips R, Haegerstrand AN. In vitro endothelialization of photooxidatively stabilized xenogeneic pericardium. Ann Thorac Surg 1995;60(2 Suppl): S365-8

[40] Kim WG, Park JK, Park YN, Hwang CM, Jo YH, Min BG, Yoon CJ, Lee TY. Tissueengineered heart valve leaflets: an effective method for seeding autologous cells on scaffolds.Int J Artif Organs 2000;23(9): 624-8

[41] Shinoka T, Shum-Tim D, Ma PX, Tanel RE, Langer R, Vacanti JP, Mayer JE Jr. Tissueengineered heart valve leaflets: does cell origin affect outcome?Circulation 1997;96(9 Suppl): II-102-7

[42] Hoffman-Kim D, Maish MS, Krueger PM, Lukoff H, Bert A, Hong T, Hopkins RA. Comparison of three myofibroblast cell sources for the tissue engineering of cardiac valves.Tissue Eng 2005;11(1-2): 288-301

[43] Appleton AJ, Appleton CT, Boughner DR, Rogers KA. Vascular smooth muscle cells as a valvular interstitial cell surrogate in heart valve tissue engineering. Tissue Eng Part A 2009;15(12): 3889-97 
[44] Hoerstrup SP, Kadner A, Melnitchouk S, Trojan A, Eid K, Tracy J, Sodian R, Visjager JF, Kolb SA, Grunenfelder J, Zund G, Turina MI. Tissue engineering of functional trileaflet heart valves from human marrow stromal cells. Circulation 2002;106(12 Suppl 1): I143-50

[45] Schmidt D, Achermann J, Odermatt B, Breymann C, Mol A, Genoni M, Zund G, Hoerstrup SP. Prenatally fabricated autologous human living heart valves based on amniotic fluid derived progenitor cells as single cell source. Circulation 2007;116(11 Suppl): I64-70

[46] Castrechini NM, Murthi P, Gude NM, Erwich JJ, Gronthos S, Zannettino A, Brennecke SP, Kalionis B. Mesenchymal stem cells in human placental chorionic villi reside in a vascular Niche. Placenta 2010;31(3): 203-12

[47] Iop L, Chiavegato A, Callegari A, Bollini S, Piccoli M, Pozzobon M, Rossi CA, Calamelli S, Chiavegato D, Gerosa G, De Coppi P and Sartore S. Different cardiovascular potential of adult and fetal-type mesenchymal stem cells in a rat model of heart cryoinjury. Cell Transplantation 2008;17: 679-694

[48] Schmidt D, Achermann J, Odermatt B, Genoni M, Zund G, Hoerstrup SP. Cryopreserved amniotic fluid-derived cells: a lifelong autologous fetal stem cell source for heart valve tissue engineering. J Heart Valve Dis 2008;17(4): 446-55

[49] Schmidt D, Mol A, Breymann C, Achermann J, Odermatt B, Gössi M, et al. Living autologous heart valves engineered from human prenatally harvested progenitors. Circulation 2006;114(1 Suppl): I125-31

[50] Sodian R, Schaefermeier P, Abegg-Zips S, Kuebler WM, Shakibaei M, Daebritz S, et al. Use of human umbilical cord blood-derived progenitor cells for tissue-engineered heart valves. Ann Thorac Surg 2010;89(3): 819-28

[51] Schmidt D, Mol A, Odermatt B, Neuenschwander S, Breymann C, Gössi M et al. Engineering of biologically active living heart valve leaflets using human umbilical cord-derived progenitor cells. Tissue Eng 2006;12(11): 3223-32

[52] Haniffa MA, Wang XN, Holtick U, Rae M, Isaacs JD, Dickinson AM, Hilkens CM, Collin MP. Adult human fibroblasts are potent immunoregulatory cells and functionally equivalent to mesenchymal stem cells. J Immunol 2007 1;179(3): 1595-604

[53] Batten P, Sarathchandra P, Antoniw JW, Tay SS, Lowdell MW, Taylor PM, et al. Human mesenchymal stem cells induce $\mathrm{T}$ cell anergy and downregulate $\mathrm{T}$ cell allo-responses via the TH2 pathway: relevance to tissue engineering human heart valves. Tissue Eng 2006;12: 2263-73

[54] Colazzo F, Sarathchandra P, Smolenski RT, Chester AH, Tseng YT, Czernuszka JT, Yacoub MH, Taylor PM. Extracellular matrix production by adipose-derived stem cells: implications for heart valve tissue engineering.Biomaterials 2011;32(1): 119-27 
[55] Vaculik C, Schuster C, Bauer W, Iram N, Pfisterer K, Kramer G, Reinisch A, Strunk D, Elbe-Bürger A. Human dermis harbors distinct mesenchymal stromal cell subsets.J Invest Dermatol 2012;132(3 Pt 1): 563-74

[56] Pittenger MF, Mackay AM, Beck S, Jaiswal RK, Douglas R, Mosca JD, et al. Multilineage potential of adult human mesenchymal stem cells. Science 1999;284: 143-7

[57] Latif N, Sarathchandra P, Thomas PS, Antoniw J, Batten P, Chester AH, et al. Characterization of structural and signaling molecules by human valve interstitial cells and comparison to human mesenchymal stem cells. J Heart Valve Dis 2007; 16:56

[58] Della Rocca F, Sartore S, Guidolin D, Bertipaglia B, Gerosa G, Casarotto D, et al. Cell composition of the human pulmonary valve: a comparative study with the aortic valve - the VESALIO Project. Vitalitate Exornatum Succedaneum Aorticum Labore Ingenioso Obtenibitur. Ann Thorac Surg 2000;70: 1594-600

[59] Sutherland FW, Perry TE, Yu Y, Sherwood MC, Rabkin E, Masuda Y, et al. From stem cells to viable autologous semilunar heart valve. Circulation 2005; 111: 2783-91

[60] Bin F, Yinglong L, Nin X, Kai F, Laifeng S, Xiaodong Z. Construction of tissue engineered homograft bioprosthetic heart valves in vitro. ASAIO J 2006;52: 303-9

[61] Sales VL, Mettler BA, Engelmayr GC Jr, Aikawa E, Bischoff J, Martin DP, Exarhopoulos A, Moses MA, Schoen FJ, Sacks MS, Mayer JE Jr. Endothelial progenitor cells as a sole source for ex vivo seeding of tissue-engineered heart valves.Tissue Eng Part A 2010;16(1): 257-67

[62] Dvorin EL, Wylie-Sears J, Kaushal S, Martin DP, Bischoff J. Quantitative evaluation of endothelial progenitors and cardiac valve endothelial cells: proliferation and differentiation on poly-glycolic acid/poly-4-hydroxybutyrate scaffold in response to vascular endothelial growth factor and transforming growth factor beta1.Tissue Eng 2003;9(3): 487-93

[63] Fang NT, Xie SZ, Wang SM, Gao HY, Wu CG, Pan LF. Construction of tissue-engineered heart valves by using decellularized scaffolds and endothelial progenitor cells.Chin Med J (Engl) 2007;120(8): 696-702

[64] Hoerstrup SP, Sodian R, Sperling JS, Vacanti JP, Mayer JE. New pulsatile bioreactor for in vitro formation of tissue engineered heart valves. Tissue engineering 2000; 6: $75-79$

[65] Ramaswamy S, Gottlieb D, Engelmayr GC Jr, Aikawa E, Schmidt DE, Gaitan-Leon DM, Sales VL, Mayer JE Jr, Sacks MS. The role of organ level conditioning on the promotion of engineered heart valve tissue development in-vitro using mesenchymal stem cells. Biomaterials 2010;31(6): 1114-25

[66] Wang L, Wilshaw SP, Korossis S, Fisher J, Jin Z, Ingham E. Factors influencing the oxygen consumption rate of aortic valve interstitial cells: application to tissue engineering. Tissue Eng Part C Methods 2009;15(3): 355-63 
[67] Warnock JN, Konduri S, He Z, Yoganathan AP.Design of a sterile organ culture system for the ex vivo study of aortic heart valves. J Biomech Eng2005;127(5): 857-61

[68] Lichtenberg A, Tudorache I, Cebotari S, Suprunov M, Tudorache G, Goerler H, Park JK, Hilfiker-Kleiner D, Ringes-Lichtenberg S, Karck M, Brandes G, Hilfiker A, Haverich A. Preclinical testing of tissue-engineered heart valves re-endothelialized under simulated physiological conditions.Circulation2006;114(1 Suppl): I559-65

[69] Jockenhoevel S, Zund G, Hoerstrup SP, Schnell A, Turina M. Cardiovascular tissue engineering: a new laminar flow chamber for in vitro improvement of mechanical tissue properties.ASAIO J2002;48(1): 8-11

[70] Engelmayr GC Jr, Sales VL, Mayer JE Jr, Sacks MS. Cyclic flexure and laminar flow synergistically accelerate mesenchymal stem cell-mediated engineered tissue formation: Implications for engineered heart valve tissues.Biomaterials 2006;27(36): 6083-95

[71] Balachandran K, Alford PW, Wylie-Sears J, Goss JA, Grosberg A, Bischoff J, Aikawa E, Levine RA, Parker KK. Cyclic strain induces dual-mode endothelial-mesenchymal transformation of the cardiac valve.Proc Natl Acad Sci USA 2011;108(50): 19943-8

[72] Sierad LN, Simionescu A, Albers C, Chen J, Maivelett J, Tedder ME, Liao J, Simionescu DT. Design and Testing of a Pulsatile Conditioning System for Dynamic Endothelialization of Polyphenol-Stabilized Tissue Engineered Heart Valves.Cardiovasc Eng Technol 2010;1(2): 138-153

[73] Breuer CK, Shin'oka T, Tanel RE, Zund G, Mooney DJ, Ma PX, Miura T, Colan S, Langer R, Mayer JE, Vacanti JP.Tissue engineering lamb heart valve leaflets.Biotechnol Bioeng 1996;50(5): 562-7

[74] Zund G, Breuer CK, Shinoka T, Ma PX, Langer R, Mayer JE, Vacanti JP. The in vitro construction of a tissue engineered bioprosthetic heart valve.Eur J Cardiothorac Surg 1997;11(3): 493-7

[75] Sodian R, Hoerstrup SP, Sperling JS, Martin DP, Daebritz S, Mayer JE Jr, Vacanti JP. Evaluation of biodegradable, three-dimensional matrices for tissue engineering of heart valves.ASAIO J 2000;46(1): 107-10

[76] Sodian R, Hoerstrup SP, Sperling JS, Daebritz SH, Martin DP, Schoen FJ, Vacanti JP, Mayer JE Jr. Tissue engineering of heart valves: in vitro experiences.Ann Thorac Surg. 2000 Jul;70(1):140-4

[77] Kadner A, Hoerstrup SP, Tracy J, Breymann C, Maurus CF, Melnitchouk S, Kadner G, Zund G, Turina M. Human umbilical cord cells: a new cell source for cardiovascular tissue engineering.Ann Thorac Surg 2002;74(4): S1422-8

[78] Kadner A, Zund G, Maurus C, Breymann C, Yakarisik S, Kadner G, Turina M, Hoerstrup SP. Human umbilical cord cells for cardiovascular tissue engineering: a comparative study.Eur J Cardiothorac Surg 2004;25(4): 635-41 
[79] Schmidt D, Breymann C, Weber A, Guenter CI, Neuenschwander S, Zund G, Turina M, Hoerstrup SP. Umbilical cord blood derived endothelial progenitor cells for tissue engineering of vascular grafts.Ann Thorac Surg 2004;78(6): 2094-8

[80] Sales VL, Engelmayr GC Jr, Johnson JA Jr, Gao J, Wang Y, Sacks MS, Mayer JE Jr. Protein precoating of elastomeric tissue-engineeringscaffolds increased cellularity, enhanced extracellular matrix protein production, and differentially regulated the phenotypes of circulating endothelial progenitor cells.Circulation 2007;116(11 Suppl): I55-63

[81] Bader A, Schilling T, Teebken OE, Brandes G, Herden T, Steinhoff G, Haverich A. Tissue engineering of heart valves--human endothelial cell seeding of detergent acellularized porcine valves. Eur J Cardiothorac Surg. 1998 Sep;14(3):279-84

[82] Cebotari S, Mertsching H, Kallenbach K, Kostin S, Repin O, Batrinac A, Kleczka C, Ciubotaru A, Haverich A. Construction of autologous human heart valves based on an acellular allograft matrix.Circulation 2002;106(12 Suppl 1): I63-I68

[83] Schenke-Layland K, Opitz F, Gross M, Döring C, Halbhuber KJ, Schirrmeister F, Wahlers T, Stock UA. Complete dynamic repopulation of decellularized heart valves by application of defined physical signals-an in vitro study.Cardiovasc Res 2003;60(3): 497-509

[84] Lichtenberg A, Tudorache I, Cebotari S, Ringes-Lichtenberg S, Sturz G, Hoeffler K, Hurscheler C, Brandes G, Hilfiker A, Haverich A. In vitro re-endothelialization of detergent decellularized heart valves under simulated physiological dynamic conditions.Biomaterials 2006;27(23): 4221-9

[85] Callegari A, Bollini S, Iop L, Chiavegato A, Torregrossa G, Pozzobon M, Gerosa G, De Coppi P, Elvassore N, Sartore S. Neovascularization induced by porous collagen scaffold implanted on intact and cryoinjured rat hearts. Biomaterials 2007;28(36): 5449-61

[86] Menon NG, Rodriguez ED, Byrnes CK, Girotto JA, Goldberg NH, Silverman RP. Revascularization of human acellular dermis in full-thickness abdominal wall reconstruction in the rabbit model. Ann Plast Surg 2003;50(5): 523-7

[87] Chue WL, Campbell GR, Caplice N, Muhammed A, Berry CL, Thomas AC, Bennett $\mathrm{MB}$, Campbell JH. Dog peritoneal and pleural cavities as bioreactors to grow autologous vascular grafts. J Vasc Surg 2004;39(4): 859-67

[88] Kalfa D, Bel A, Chen-Tournoux A, Della Martina A, Rochereau P, Coz C, Bellamy V, Bensalah M, Vanneaux V, Lecourt S, Mousseaux E, Bruneval P, Larghero J, Menasché P. A polydioxanone electrospun valved patch to replace the right ventricular outflow tract in a growing lamb model.Biomaterials 2010;31(14): 4056-63

[89] Steinhoff G, Stock U, Karim N, Mertsching H, Timke A, Meliss RR, Pethig K, Haverich A, Bader A. Tissue engineering of pulmonary heart valves on allogenic acellular 
matrix conduits: in vivo restoration of valve tissue.Circulation 2000;102(19 Suppl 3): III50-5

[90] Dohmen PM, Ozaki S, Yperman J, Flameng W, Konertz W. Lack of calcification of tissue engineered heart valves in juvenile sheep.Semin Thorac Cardiovasc Surg 2001;13(4 Suppl 1): 93-8

[91] Lutter G, Metzner A, Jahnke T, Bombien R, Boldt J, Iino K, Cremer J, Stock UA. Percutaneous tissue-engineered pulmonary valved stent implantation.Ann Thorac Surg 2010;89(1): 259-63

[92] Perri G, Polito A, Esposito C, Albanese SB, Francalanci P, Pongiglione G, Carotti A. Early and late failure of tissue-engineered pulmonary valve conduits used for right ventricular outflow tract reconstruction in patients with congenital heart disease. Eur J Cardiothorac Surg 2012;41(6): 1320-5

[93] Cebotari S, Lichtenberg A, Tudorache I, Hilfiker A, Mertsching H, Leyh R, Breymann T, Kallenbach K, Maniuc L, Batrinac A, Repin O, Maliga O, Ciubotaru A, Haverich A. Clinical application of tissue engineered human heart valves using autologous progenitor cells. Circulation 2006;114(1 Suppl): I132-7

[94] Dohmen PM, Lembcke A, Holinski S, Pruss A, Konertz W. Ten years of clinical results with a tissue-engineered pulmonary valve. Ann Thorac Surg 2011;92(4): 1308-14

[95] Weber B, Scherman J, Emmert MY, Gruenenfelder J, Verbeek R, Bracher M, Black M, Kortsmit J, Franz T, Schoenauer R, Baumgartner L, Brokopp C, Agarkova I, Wolint P, Zund G, Falk V, Zilla P, Hoerstrup SP. Injectable living marrow stromal cell-based autologous tissue engineered heart valves: first experiences with a one-step intervention in primates.Eur Heart J 2011;32(22): 2830-40

[96] Emmert MY, Weber B, Behr L, Frauenfelder T, Brokopp CE, Grünenfelder J, Falk V, Hoerstrup SP. Transapical aortic implantation of autologous marrow stromal cellbased tissue-engineered heart valves: first experiences in the systemic circulation.JACC Cardiovasc Interv 2011;4(7): 822-3

[97] Emmert MY, Weber B, Wolint P, Behr L, Sammut S, Frauenfelder T, Frese L, Scherman J, Brokopp CE, Templin C, Grünenfelder J, Zünd G, Falk V, Hoerstrup SP. Stem cell-based transcatheter aortic valve implantation: first experiences in a pre-clinical model.JACC Cardiovasc Interv 2012;5(8): 874-83

[98] Vincentelli A, Wautot F, Juthier F, Fouquet O, Corseaux D, Marechaux S, Le Tourneau T, Fabre O, Susen S, Van Belle E, Mouquet F, Decoene C, Prat A, Jude B. In vivo autologous recellularization of a tissue-engineered heart valve: are bone marrow mesenchymal stem cells the best candidates? J Thorac Cardiovasc Surg 2007;134(2): 424-32

[99] Dohmen PM, da Costa F, Yoshi S, Lopes SV, da Souza FP, Vilani R, Wouk AF, da Costa M, Konertz W. Histological evaluation of tissue-engineered heart valves im- 
planted in the juvenile sheep model: is there a need for in-vitro seeding? J Heart Valve Dis 2006;15(6): 823-9

[100] Dohmen PM, da Costa F, Holinski S, Lopes SV, Yoshi S, Reichert LH, Villani R, Posner $S$, Konertz W. Is there a possibility for a glutaraldehyde-free porcine heart valve to grow? Eur Surg Res 2006;38(1): 54-61

[101] Affonso da Costa FD, Dohmen PM, Lopes SV, Lacerda G, Pohl F, Vilani R, Affonso Da Costa MB, Vieira ED, Yoschi S, Konertz W, Affonso da Costa I. Comparison of cryopreserved homografts and decellularized porcine heterografts implanted in sheep.Artif Organs 2004;28(4): 366-70

[102] Hopkins RA, Jones AL, Wolfinbarger L, Moore MA, Bert AA, Lofland GK. Decellularization reduces calcification while improving both durability and 1-year functional results of pulmonary homograft valves in juvenile sheep. J Thorac Cardiovasc Surg 2009;137(4):907-13, 913e1-4

[103] Baraki H, Tudorache I, Braun M, Höffler K, Görler A, Lichtenberg A, Bara C, Calistru A, Brandes G, Hewicker-Trautwein M, Hilfiker A, Haverich A, Cebotari S. Orthotopic replacement of the aortic valve with decellularized allograft in a sheep model.Biomaterials 2009;30(31): 6240-6

[104] Muratov R, Britikov D, Sachkov A, Akatov V, Soloviev V, Fadeeva I, Bockeria L. New approach to reduce allograft tissue immunogenicity. Experimental data. Interact Cardiovasc Thorac Surg 2010;10(3): 408-12

[105] Costa F, Dohmen P, Vieira E, Lopes SV, Colatusso C, Pereira EW, Matsuda CN, Cauduro S. Ross Operation with decellularized pulmonary allografts: medium-term results. Rev Bras Cir Cardiovasc 2007;22(4): 454-62

[106] CebotariS, Tudorache I, Ciubotaru A, Boethig D, Sarikouch S, Goerler A, Lichtenberg A, Cheptanaru E, Barnaciuc S, Cazacu A, Maliga O, Repin O, Maniuc L, Breymann T, Haverich A. Use of freshdecellularizedallografts for pulmonary valve replacement may reduce the reoperation rate in children and young adults: early report. Circulation 2011;124(11 Suppl): S115-23

[107] Brown JW, Elkins RC, Clarke DR, Tweddell JS, Huddleston CB, Doty JR, Fehrenbacher JW, Takkenberg JJ. Performance of the CryoValve SG human decellularized pulmonary valve in 342 patients relative to the conventional CryoValve at a mean follow-up of four years. J Thorac Cardiovasc Surg 2010;139(2): 339-48

[108] Burch PT, Kaza AK, Lambert LM, Holubkov R, Shaddy RE, Hawkins JA. Clinical performance of decellularized cryopreserved valved allografts compared with standard allografts in the right ventricular outflow tract. Ann Thorac Surg 2010;90(4): $1301-5$

[109] Erdbrugger W, Konertz W, Dohmen PM, Posner S, Ellerbrok H, Brodde OE, Robenek H, Modersohn D, Pruss A, Holinski S, Stein-Konertz M, Pauli G. Decellularized xen- 
ogeneic heart valves reveal remodeling and growth potential in vivo. Tissue Eng 2006;12(8): 2059-68

[110] Konertz W, Angeli E, Tarusinov G, Christ T, Kroll J, Dohmen PM, Krogmann O, Franzbach B, Pace Napoleone C, Gargiulo G. Right ventricular outflow tract reconstruction with decellularized porcine xenografts in patients with congenital heart disease. J Heart Valve Dis 2011;20(3): 341-7

[111] Bloch O, Golde P, Dohmen PM, Posner S, Konertz W, Erdbrügger W.Immune response in patients receiving a bioprosthetic heart valve: lack of response with decellularized valves. Tissue Eng Part A 2011;17(19-20): 2399-405

[112] Rüffer A, Purbojo A, Cicha I, Glöckler M, Potapov S, Dittrich S, Cesnjevar RA. Early failure of xenogenous de-cellularised pulmonary valve conduits--a word of caution! Eur J Cardiothorac Surg2010;38(1): 78-85

[113] Cicha I, Rüffer A, Cesnjevar R, Glöckler M, Agaimy A, Daniel WG, Garlichs CD, Dittrich S. Early obstruction of decellularized xenogenic valves in pediatric patients: involvement of inflammatory and fibroproliferative processes.Cardiovasc Pathol 2011;20(4): 222-31

[114] Simon P, Kasimir MT, Seebacher G, Weigel G, Ulrich R, Salzer U, Rieder E and Wolner E. Early failure of the tissue engineered porcine heart valve Synergraft ${ }^{\mathrm{TM}}$ in paediatric patients. Eur J Cardiothorac Surg 2003;23: 1002-6

[115] Sprangers B, Waer M, Billiau AD. Xenograft rejection-all that glitters is not Gal. Nephrol Dial Transplant 2006;21: 1486-8

[116] Terasaki PI, Cecka JM, Gjertson DW, Takemoto S, Cho YW, Yuge J. Risk rate and long-term kidney transplant survival. Clin Transpl 1996: 443-58

[117] Billingham ME, Cary NR, Hammond ME, Kemnitz J, Marboe C, McCallister HA, Snovar DC, Winters GL, Zerbe A. A working formulation for the standardization of nomenclature in the diagnosis of heart and lung rejection: Heart Rejection Study Group. The International Society for Heart Transplantation. J Heart Transplant 1990;9(6): 587-93

[118] Edge ASB, Gosse ME and Dinsmore J. Xenogeneic cell therapy: current progress and future developments in porcine cell transplantation. Cell Transplant 1998;7: 525-539

[119] Kobayashi T, Taniguchi S, Neethling FA, Rose A, Hancock WW, Ye Y, Niekrasz M, Kosanke S, Wright JL,White DJG and Cooper DKC. Delayed xenograft rejection of pig-to-baboon cardiac transplants after cobra venom factor therapy. Transplantation 1997; 64: 1255-1261

[120] Galili U, Clark MR, Shohet SB, Buehler J, Macher BA. Evolutionary relationship between the natural anti-Gal antibody and the Gal alpha 1-3Gal epitope in primates. Proc Natl Acad Sci USA 1987;84: 1369-1373 
[121] Galili U, Shohet SB, Kobrin E, Stults CL, Macher BA. Man, apes, and Old World monkeys differ from other mammals in the expression of alpha-galactosyl epitopes on nucleated cells. J Biol Chem 1988;263(33): 17755-62

[122] Galili U, Rachmilewitz EA, Peleg A, Flechner I. A unique natural human IgG antibody with anti-alphagalactosyl specificity. J Exp Med 1984;160(5): 1519-31

[123] Galili U, Mandrell RE, Hamadeh RM, Shohet SB, Griffiss JM. Interaction between human natural anti-alphagalactosyl immunoglobulin $G$ and bacteria of the human flora. Infect Immun 1988;56(7):1730

[124] Cooper DK, Good AH, Koren E, Oriol R, Malcolm AJ, Ippolito RM, Neethling FA, Ye Y, Romano E, Zuhdi N. Identification of alpha-galactosyl and other carbohydrate epitopes that are bound by human anti-pig antibodies: relevance to discordant xenografting in man. Transpl Immunol 1993;1(3): 198-205

[125] Koren E, Kujundzic M, Koscec M, Neethling FA, Richards SV, Ye Y, Zuhdi N, Cooper DK. Cytotoxic effects of human preformed anti-Gal IgG and complement on cultured pig cells. Transplant Proc 1994;26(3): 1336-9

[126] Alwayn IPJ, Basker M, Buhler L and Cooper DKC. The problem of anti-pig antibodies in pig-to-primate xenografting: current and novel methods of depletion and/or suppression of production of anti-pig antibodies. Xenotransplantation 1999; 6: $157-168$

[127] Kozlowski T, Shimizu A, Lambrigts D, Yamada K, Fuchimoto Y, Glaser R, Monroy R, Xu Y, Awwad M, Colvin RB, Cosimi AB, Robson SC, Fishman J, Spitzer TR, Cooper $\mathrm{DKC}$, Sachs DH. Porcine kidney and heart transplantations in baboons undergoing a tolerance induction regimen and antibody adsorption. Transplantation 1999;67: 18-30

[128] Schmoeckel M, Bhatti FN, Zaidi A, Cozzi E, Waterworth PD, Tolan MJ, Pino-Chavez G, Goddard M, Warner RG, Langford GA, Dunning JJ, Wallwork J, White DJ. Orthotopic heart transplantation in a transgenic pig-to-primate model. Transplantation 1998;65: 1570-7

[129] Minanov OP, Artrip JH, Szabolcs M, Kwiatkowski PA, Galili U, Itescu S, Michler RE. Triple immunosuppresion reduces mononuclear cell infiltration and prolongs graft life in pig-to-newborn baboon cardiac xenotransplantation. J Thorac Cardiovasc Surg 1998;115: 998-1006

[130] Lam TT, Paniagua R, Shivaram G, Schuurman HJ, Borie DC, Morris RE. Anti-nonGal porcine endothelial cell antibodies in acute humoral xenograft rejection of hDAFtransgenic porcine hearts in cynomolgus monkeys. Xenotransplantation 2004;11: 531-535

[131] Costa C, Zhao L, Burton WV, Bondioli KR, Williams BL, Hoagland TA, Di Tullio PA, Ebert KM and Fodor WL. Expression of $\alpha 1-2$-fucosyltransferase in transgenic pigs 
modifies the surface carbohydrate phenotype and confers resistance to human serum-mediated cytolysis. FASEB J 1999;6: 6-11

[132] Cozzi E, Yannoutsous N, Langford GA, Pino-Chavez G, Wallwork B and White DJG. Effect of transgenic expression of human decay-accelerating factor on the inhibition of hyperacute rejection of pig organs. In Xenotransplantation by Cooper DKC and Kemp E, pp. 665-682, Springer-Verlag, Berlin

[133] Kuwaki K, Tseng YL, Dor FJMF, et al. Heart transplantation in baboons using $\alpha 1,3-$ galactosyltransferase gene-knockout pigs as donors: initial experience. Nat Med 2005;11: 29-31

[134] Kasimir MT, Rieder E, Seebacher G, Wolner E, Weigel G and Simon P. Presence and elimination of the xenoantigen $\mathrm{Gal}(\alpha 1-3)$ Gal in tissue-engineered heart valves. Tissue Engineering 2005;11: 1274-1280

[135] Naso F, Gandaglia A, Iop L, Spina M, Gerosa G. Alpha-Gal detectors in xenotransplantation research: a word of caution.Xenotransplantation 2012;19(4): 215-20

[136] Naso F, Gandaglia A, Iop L, Spina M, Gerosa G. First quantitative assay of alpha-Gal in soft tissues: presence and distribution of the epitope before and after cell removal from xenogeneic heart valves.Acta Biomater 2011;7(4): 1728-34

[137] Dijkman PE, Driessen-Mol A, Frese L, Hoerstrup SP, Baaijens FP. Decellularized homologous tissue-engineered heart valves as off-the-shelf alternatives to xeno- and homografts. Biomaterials 2012;33(18): 4545-54

[138] Krug EL, Markwald RR. Extracellular cardiac proteins activate chick endothelial transition to prevalvular mesenchyme. Prog Clin Biol Res1986;217B: 195-8

[139] de Lange FJ, Moorman AFM, Anderson H, Maenner J,. Soufan AT, de Gier-de Vries C, Schneider MD, Webb S, van den Hoff MJB, Christoffels VM. Lineage and Morphogenetic Analysis of the Cardiac Valves. Circ Res 2004;95; 645-654

[140] Snider P, Olaopa M, Firulli AB, Conway SJ. Cardiovascular Development and the Colonizing Cardiac Neural Crest Lineage. The Scientific World Journal 2007;7: 10901113

[141] Eisenberg LM, Markwald RR. Molecular Regulation of Atrioventricular Valvulo-septal Morphogenesis. Circulation Research 1995; 77:1-6

[142] von Wattenwyl R, Blumenthal B, Heilmann C, Golsong P, Poppe A, Beyersdorf F, Siepe M.Scaffold-based transplantation of vascular endothelial growth factor-overexpressing stem cells leads to neovascularization in ischemic myocardium but did not show a functional regenerative effect.ASAIO J 2012;58(3): 268-74

[143] Noiseux N, Gnecchi M, Lopez-Ilasaca M, Zhang L, Solomon SD, Deb A, Dzau VJ, Pratt RE. Mesenchymal stem cells overexpressing Akt dramatically repair infarcted 
myocardium and improve cardiac function despite infrequent cellular fusion or differentiation.Mol Ther 2006;14(6): 840-50

[144] Takahashi K, Tanabe K, Ohnuki M, Narita M, Ichisaka T, Tomoda K, Yamanaka S.Induction of pluripotent stem cells from adult human fibroblasts by defined factors.Cell 2007;131(5): 861-72

[145] Jung CB, Moretti A, Mederos y Schnitzler M, Iop L, Storch U, Bellin M, Dorn T, Ruppenthal S, Pfeiffer S, Goedel A, Dirschinger RJ, Seyfarth M, Lam JT, Sinnecker D, Gudermann T, Lipp P, Laugwitz KL. Dantrolene rescues arrhythmogenic RYR2 defect in a patient-specific stem cell model of catecholaminergic polymorphic ventricular tachycardia.EMBO Mol Med 2012;4(3): 180-91

[146] Templin C, Zweigerdt R, Schwanke K, Olmer R, Ghadri JR, Emmert MY, Müller E, Küest SM, Cohrs S, Schibli R, Kronen P, Hilbe M, Reinisch A, Strunk D, Haverich A, Hoerstrup S, Lüscher TF, Kaufmann PA, Landmesser U, Martin U. Transplantation and tracking of human-induced pluripotent stem cells in a pig model of myocardial infarction: assessment of cell survival, engraftment, and distribution by hybrid single photon emission computed tomography/computed tomography of sodium iodide symporter transgene expression. Circulation 2012;126(4): 430-9

[147] Armstrong EJ and Bischoff J. Heart Valve Development: Endothelial Cell Signaling and Differentiation. Circ Res 2004;95; 459-470

[148] Combs MD and Yutzey KE. VEGF and RANKL Regulation of NFATc1 in Heart Valve Development. Circ Res 2009;105; 565-574

[149] de la Pompa JL. Notch Signaling in Cardiac Development and Disease. Pediatr Cardiol 2009;30: 643-650

[150] Rivera-Feliciano J, Tabin CJ. Bmp2 instructs cardiac progenitors to form the heartvalve-inducing field. Developmental Biology 2006;295:580-588

[151] MCCulley DJ, Kang J, Martin JF, Black BL. BMP4 is required in the anterior heart field and its derivatives for endocardial cushion remodeling, outflow tract septation, and semilunar valve development. Developmental Dynamics 2008;237: 3200-3209

[152] Lincoln J, Kist R, Scherer G, Yutzey KE. Sox9 is required for precursor cell expansion and extracellular matrix organization during mouse heart valve development. Developmental Biology 2007;305: 120-132

[153] Lie-Venema H, Eralp I, Markwald RR, van den Akker NM, Wijffels MC, Kolditz DP, van der Laarse A, Schalij MJ, Poelmann RE, Bogers AJ, Gittenberger-de Groot AC. Periostin expression by epicardium-derived cells is involved in the development of the atrioventricular valves and fibrous heart skeleton. Differentiation 2008;76(7): 809-19

[154] Norris RA, Potts JD, Yost MJ, Junor L, Brooks T, Tan H, Hoffman S, Hart MM,. Kern MJ, Damon B, Markwald RR, Goodwin RL. Periostin Promotes a Fibroblastic Lineage 
Pathway in Atrioventricular Valve Progenitor Cells. Developmental Dynamics 2009;238: 1052-1063

[155] Scherz PJ, Huisken J, Sahai-Hernandez P, Stainier DYR. High-speed imaging of developing heart valves reveals interplay of morphogenesis and function. Development 2008;135: 1179-1187

[156] Ghosh AK, Nagpal V, Covington JW, Michaels MA, Vaughan DE. Molecular basis of cardiac endothelial-to-mesenchymaltransition (EndMT): differential expression of microRNAs during EndMT. Cell Signal 2012;24(5): 1031-6

[157] Hong H, Dong N, Shi J, Chen S, Guo C, Hu P, Qi H. Fabrication of a novel hybrid heart valve leaflet for tissue engineering: an in vitro study.Artif Organs2009;33(7): $554-8$

[158] Paruchuri S, Yang JH, Aikawa E, Melero-Martin JM, Khan ZA, Loukogeorgakis S, Schoen FJ, Bischoff J. Human pulmonary valve progenitor cells exhibit endothelial/ mesenchymal plasticity in response to vascular endothelial growth factor-A and transforming growth factor-beta2. Circ Res 2006;99(8): 861-9

[159] Chiu YN, Norris RA, Mahler G, Recknagel A, Butcher JT. Transforming growth factor $\beta$, bone morphogenetic protein, and vascular endothelial growth factor mediate phenotype maturation and tissue remodeling by embryonic valve progenitor cells: relevance for heart valve tissue engineering. Tissue Eng Part A 2010;16(11): 3375-83

[160] Sewell-Loftin MK, Chun YW, Khademhosseini A, Merryman WD. EMT-inducing biomaterials for heart valve engineering: taking cues from developmental biology.J Cardiovasc Transl Res 2011;4(5): 658-71

[161] Ramamurthi A, Vesely I. Evaluation of the matrix-synthesis potential of crosslinked hyaluronan gels for tissue engineering of aortic heart valves.Biomaterials2005;26(9): 999-1010

[162] Camci-Unal G, Nichol JW, Bae H, Tekin H, Bischoff J, Khademhosseini A. Hydrogel surfaces to promote attachment and spreading of endothelial progenitor cells.J Tissue Eng Regen Med 2012; doi: 10.1002/term.517

[163] Koens MJ, Faraj KA, Wismans RG, van der Vliet JA, Krasznai AG, Cuijpers VM, Jansen JA, Daamen WF, van Kuppevelt TH. Controlled fabrication of triple layered and molecularly defined collagen/elastin vascular grafts resembling the native blood vessel.Acta Biomater 2010;6(12): 4666-74

[164] Smith MD, Shearer MG, Srivastava S, Scott R, Courtney JM. Quantitative evaluation of the growth of established cell lines on the surface of collagen, collagen composite and reconstituted basement membrane.Urol Res 1992;20(4): 285-8

[165] Taite LJ, Yang P, Jun HW, West JL. Nitric oxide-releasing polyurethane-PEG copolymer containing the YIGSR peptide promotes endothelialization with decreased platelet adhesion.J Biomed Mater Res B Appl Biomater 2008;84(1): 108-16 
[166] Andukuri A, Minor WP, Kushwaha M, Anderson JM, Jun HW. Effect of endothelium mimicking self-assembled nanomatrices on cell adhesion and spreading of human endothelial cells and smooth muscle cells.Nanomedicine 2010;6(2): 289-97

[167] Blindt R, Vogt F, Astafieva I, Fach C, Hristov M, Krott N, Seitz B, Kapurniotu A, Kwok C, Dewor M, Bosserhoff AK, Bernhagen J, Hanrath P, Hoffmann R, Weber C. A novel drug-eluting stent coated with an integrin-binding cyclic Arg-Gly-Asp peptide inhibits neointimal hyperplasia by recruiting endothelial progenitor cells.J Am Coll Cardiol2006;47(9): 1786-95

[168] einhart JG, Schense JC, Schima H, Gorlitzer M, Hubbell JA, Deutsch M, Zilla P. Enhanced endothelial cell retention on shear-stressed synthetic vascular grafts precoated with RGD-cross-linked fibrin.Tissue Eng2005;11(5-6): 887-95

[169] Andrieux A, Rabiet MJ, Chapel A, Concord E, Marguerie G. A highly conserved sequence of the Arg-Gly-Asp-binding domain of the integrin beta 3 subunit is sensitive to stimulation.J Biol Chem1991;266(22): 14202-7

[170] Hasegawa T, Okada K, Takano Y, Hiraishi Y, Okita Y. Autologous fibrin-coated small-caliber vascular prostheses improve antithrombogenicity by reducing immunologic response.J Thorac Cardiovasc Surg2007;133(5): 1268-76

[171] Flanagan TC, Cornelissen C, Koch S, Tschoeke B, Sachweh JS, Schmitz-Rode T, Jockenhoevel $\mathrm{S}$. The in vitro development of autologous fibrin-based tissue-engineered heart valves through optimised dynamic conditioning.Biomaterials 2007;28(23): 3388-97

[172] Veleva AN, Heath DE, Cooper SL, Patterson C. Selective endothelial cell attachment to peptide-modified terpolymers.Biomaterials2008;29(27): 3656-61

[173] Rodas AC, Polak R, Hara PH, Lee EI, Pitombo RN, Higa OZ. Cytotoxicity and endothelial cell adhesion of lyophilized and irradiated bovine pericardium modified with silk fibroin and chitosan.Artif Organs 2011;35(5): 502-7

[174] Sarathchandra P, Smolenski RT, Yuen AH, Chester AH, Goldstein S, Heacox AE, Yacoub MH, Taylor PM. Impact of $\gamma$-Irradiation on Extracellular Matrix of Porcine Pulmonary Valves.J Surg Res 2012;176(2): 376-85

[175] Li S, Henry JJ. Nonthrombogenic approaches to cardiovascular bioengineering.Annu Rev Biomed Eng 2011;13: 451-75

[176] Hashi CK, Zhu Y, Yang GY, Young WL, Hsiao BS, Wang K, Chu B, Li S. Antithrombogenic property of bone marrow mesenchymal stem cells in nanofibrous vascular grafts. Proc Natl Acad Sci USA 2007;104(29): 11915-20

[177] Kito H, Matsuda T. Biocompatible coatings for luminal and outer surfaces of smallcaliber artificial grafts.J Biomed Mater Res 1996;30(3): 321-30 
[178] Gombotz WR, Wang GH, Horbett TA, Hoffman AS. Protein adsorption to poly(ethylene oxide) surfaces.J Biomed Mater Res 1991;25(12): 1547-62

[179] Jordan SW, Faucher KM, Caves JM, Apkarian RP, Rele SS, Sun XL, Hanson SR, Chaikof EL. Fabrication of a phospholipid membrane-mimetic film on the luminal surface of an ePTFE vascular graft. Biomaterials 2006;27(18): 3473-81

[180] Koo J, Galanakis D, Liu Y, Ramek A, Fields A, Ba X, Simon M, Rafailovich MH. Control of anti-thrombogenic properties: surface-induced self-assembly of fibrinogen fibers. Biomacromolecules 2012;13(5): 1259-68

[181] Smith DJ, Chakravarthy D, Pulfer S, Simmons ML, Hrabie JA, Citro ML, Saavedra JE, Davies KM, Hutsell TC, Mooradian DL, Hanson SR, Keefer LK. Nitric oxide-releasing polymers containing the [N(O)NO]- group.J Med Chem 1996;39(5): 1148-56

[182] Kolpakov V, Gordon D, Kulik TJ. Nitric oxide-generating compounds inhibit total protein and collagen synthesis in cultured vascular smooth muscle cells.Circ Res 1995;76(2): 305-9

[183] Yu J, Zhang Y, Zhang X, Rudic RD, Bauer PM, Altieri DC, Sessa WC. Endothelium derived nitric oxide synthase negatively regulates the PDGF-survivin pathway during flow-dependent vascular remodeling. PLoS One 2012;7(2): e31495

[184] Marks DS, Vita JA, Folts JD, Keaney JF Jr, Welch GN, Loscalzo J. Inhibition of neointimal proliferation in rabbits after vascular injury by a single treatment with a protein adduct of nitric oxide.J Clin Invest 1995;96(6): 2630-8

[185] Acharya G, Hopkins RA, Lee CH. Advanced polymeric matrix for valvular complications.J Biomed Mater Res A 2012;100(5): 1151-9

[186] De Scheerder I, Wang K, Wilczek K, Meuleman D, Van Amsterdam R, Vogel G, Piessens J, Van de Werf F. Experimental study of thrombogenicity and foreign body reaction induced by heparin-coated coronary stents.Circulation 1997;95(6): 1549-53

[187] Lahann J, Plüster W, Klee D, Gattner HG, Höcker H. Immobilization of the thrombin inhibitor r-hirudin conserving its biological activity.J Mater Sci Mater Med 2001;12(9): 807-10

[188] Hashi CK, Derugin N, Janairo RR, Lee R, Schultz D, Lotz J, Li S. Antithrombogenic modification of small-diameter microfibrous vascular grafts.Arterioscler Thromb Vasc Biol 2010;30(8): 1621-7

[189] Pastore CJ, Isner JM, Bacha PA, Kearney M, Pickering JG. Epidermal growth factor receptor-targeted cytotoxin inhibits neointimalhyperplasia in vivo. Results of local versus systemic administration.Circ Res 1995;77(3): 519-29

[190] Asahara T, Bauters C, Pastore C, Kearney M, Rossow S, Bunting S, Ferrara N, Symes JF, Isner JM. Local delivery of vascular endothelial growth factor accelerates reendo- 
thelialization and attenuates intimal hyperplasia in balloon-injured rat carotid artery.Circulation 1995;91(11): 2793-801

[191] Leppänen O, Rutanen J, Hiltunen MO, Rissanen TT, Turunen MP, Sjöblom T, Brüggen J, Bäckström G, Carlsson M, Buchdunger E, Bergqvist D, Alitalo K, Heldin CH, Ostman A, Ylä-Herttuala S. Oral imatinib mesylate (STI571/gleevec) improves the efficacy of local intravascular vascular endothelial growth factor-C gene transfer in reducing neointimal growth in hypercholesterolemic rabbits.Circulation 2004;109(9): $1140-6$

[192] Sirois MG, Simons M, Edelman ER. Antisense oligonucleotide inhibition of PDGFRbeta receptor subunit expression directs suppression of intimal thickening.Circulation 1997;95(3): 669-76

[193] Coleman KR, Braden GA, Willingham MC, Sane DC. Vitaxin, a humanized monoclonal antibody to the vitronectin receptor (alphavbeta3), reduces neointimalhyperplasia and total vessel area after balloon injury in hypercholesterolemic rabbits.Circ Res 1999;84(11): 1268-76

[194] Miniati DN, Hoyt EG, Feeley BT, Poston RS, Robbins RC.Circulation 2000;102(19 Suppl 3): III237-42

[195] Skelly CL, Curi MA, Meyerson SL, Woo DH, Hari D, Vosicky JE, Advani SJ, Mauceri HJ, Glagov S, Roizman B, Weichselbaum RR, Schwartz LB. Prevention of restenosis by a herpes simplex virus mutant capable of controlled long-term expression in vascular tissue in vivo.Gene Ther 2001;8(24): 1840-6

[196] Mallawaarachchi CM, Weissberg PL, Siow RC. Smad7 gene transfer attenuates adventitial cell migration and vascular remodeling after balloon injury.Arterioscler Thromb Vasc Biol2005;25(7): 1383-7

[197] Mallawaarachchi CM, Weissberg PL, Siow RC. Antagonism of platelet-derived growth factor by perivascular gene transfer attenuates adventitial cell migration after vascular injury: new tricks for old dogs?FASEB J2006;20(10): 1686-1688

[198] Garcia-Touchard A, Burke SE, Toner JL, Cromack K, Schwartz RS. Zotarolimus-eluting stents reduce experimental coronary artery neointimal hyperplasia after 4 weeks. Eur Heart J 2006;27(8): 988-93

[199] Chen YW, Smith ML, Sheets M, Ballaron S, Trevillyan JM, Burke SE, Rosenberg T, Henry C, Wagner R, Bauch J, Marsh K, Fey TA, Hsieh G, Gauvin D, Mollison KW, Carter GW, Djuric SW. Zotarolimus, a novel sirolimus analogue with potent antiproliferative activity on coronary smooth muscle cells and reduced potential for systemic immunosuppression.J Cardiovasc Pharmacol 2007;49(4): 228-35

[200] Zhao L, Ding T, Cyrus T, Cheng Y, Tian H, Ma M, Falotico R, Praticò D. Low-dose oral sirolimus reduces atherogenesis, vascular inflammation and modulates plaque composition in mice lacking the LDL receptor.Br J Pharmacol 2009;156(5): 774-85 
[201] Patel JK, Kobashigawa JA. Everolimus for cardiac allograft vasculopathy--every patient, at any time?Transplantation. 2011 Jul 27;92(2):127-8

[202] Baek I, Bai CZ, Hwang J, Park J, Park JS, Kim DJ. Suppression of neointimalhyperplasia by sirolimus-eluting expanded polytetrafluoroethylene (ePTFE) haemodialysis grafts in comparison with paclitaxel-coated grafts.Nephrol Dial Transplant 2012;27(5): 1997-2004

[203] Thiene G, Valente M. Calcification of valve bioprosthesis: the cardiac surgeon's nightmare. Eur J Cardiothorac Surg 1994;8(9): 476-8

[204] Pettenazzo E, Deiwick M, Thiene G, Molin G, Glasmacher B, Martignago F, Bottio T, Reul H, Valente M. Dynamic in vitro calcification of bioprosthetic porcine valves: evidence of apatite crystallization. J Thorac Cardiovasc Surg 2001;121(3): 500-9

[205] Zhai W, Chang J, Lü X, Wang Z. Procyanidins-crosslinked heart valve matrix: anticalcification effect.J Biomed Mater Res B Appl Biomater 2009;90(2): 913-21

[206] Pettenazzo E, Valente M, Thiene G. Octanediol treatment of glutaraldehyde fixed bovine pericardium: evidence of anticalcification efficacy in the subcutaneous rat model.Eur J Cardiothorac Surg 2008;34(2): 418-22

[207] Lim HG, Kim SH, Choi SY, Kim YJ. Anticalcification effects of decellularization, solvent, and detoxification treatment for genipin and glutaraldehyde fixation of bovine pericardium.Eur J Cardiothorac Surg 2012;41(2): 383-90

[208] Connolly JM, Bakay MA, Alferiev IS, Gorman RC, Gorman JH 3rd, Kruth HS, Ashworth PE, Kutty JK, Schoen FJ, Bianco RW, Levy RJ. Triglycidyl amine crosslinking combined with ethanol inhibits bioprosthetic heart valve calcification.Ann Thorac Surg 2011;92(3): 858-65

[209] Sacks MS, Hamamoto H, Connolly JM, Gorman RC, Gorman JH 3rd, Levy RJ. In vivo biomechanical assessment of triglycidylamine crosslinked pericardium. Biomaterials 2007;28(35): 5390-8

[210] Koutsopoulos S, Kontogeorgou A, Dalas E, Petroheilos J. Calcification of porcine and human cardiac valves: testing of various inhibitors for antimineralization. J Mater Sci Mater Med 1998;9(7): 421-4

[211] da Costa FD, Costa AC, Prestes R, Domanski AC, Balbi EM, Ferreira AD, Lopes SV. The early and midterm function of decellularized aortic valve allografts.Ann Thorac Surg 2010;90(6): 1854-60

[212] Rodríguez M, Aguilera-Tejero E, Mendoza FJ, Guerrero F, López I. Effects of calcimimetics on extraskeletal calcifications in chronic kidney disease. Kidney Int Suppl 2008;(111): S50-4 
[213] Jung S, Querfeld U, Müller D, Rudolph B, Peters H, Krämer S. Submaximal suppression of parathyroid hormone ameliorates calcitriol-induced aortic calcification and remodeling and myocardial fibrosis in uremic rats. J Hypertens 2012;30(11): 2182-91

[214] Alferiev I, Vyavahare N, Song C, Connolly J, Hinson JT, Lu Z, Tallapragada S, Bianco $\mathrm{R}$, Levy R. Bisphosphonate derivatized polyurethanes resist calcification.Biomaterials 2001;22(19): 2683-93

[215] Ng KE, Joly P, Jayasinghe SN, Vernay B, Knight R, Barry SP, McComick J, Latchman $\mathrm{D}$, Stephanou A. Bio-electrospraying primary cardiac cells: in vitro tissue creation and functional study.Biotechnol J 2011;6(1): 86-95

[216] Kaminski A, Klopsch C, Mark P, Yerebakan C, Donndorf P, Gäbel R, Eisert F, Hasken S, Kreitz S, Glass A, Jockenhövel S, Ma N, Kundt G, Liebold A, Steinhoff G. Autologous valve replacement-CD133+ stem cell-plus-fibrin composite-based sprayed cell seeding for intraoperative heart valvetissue engineering.Tissue Eng Part C Methods 2011;17(3): 299-309

[217] Lin Q, Ding X, Qiu F, Song X, Fu G, Ji J. In situ endothelialization of intravascular stents coated with an anti-CD34 antibody functionalized heparin-collagen multilayer.Biomaterials 2010;31(14): 4017-25

[218] Ye X, Zhao Q, Sun X, Li H. Enhancement of mesenchymal stem cell attachment to decellularized porcine aortic valve scaffold by in vitro coating with antibody against CD90: a preliminary study on antibody-modified tissue-engineered heart valve. Tissue Eng Part A 2009;15(1): 1-11

[219] Jordan JE, Williams JK, Lee SJ, Raghavan D, Atala A, Yoo JJ. Bioengineered self-seeding heart valves.J Thorac Cardiovasc Surg 2012;143(1): 201-8

[220] Hoffmann J, Paul A, Harwardt M, Groll J, Reeswinkel T, Klee D, Moeller M, Fischer H, Walker T, Greiner T, Ziemer G, Wendel HP. Immobilized DNA aptamers used as potent attractors for porcine endothelial precursor cells.J Biomed Mater Res A 2008;84(3): 614-21

[221] Schleicher M, Wendel HP, Fritze O, Stock UA. In vivo tissue engineering of heart valves: evolution of a novel concept.Regen Med 2009;4(4): 613-9

[222] Sun W, Darling A, Starly B, Nam J. Computer-aided tissue engineering: overview, scope and challenges. Biotechnol Appl Biochem 2004;39(Pt 1): 29-47

[223] Lalan S, Pomerantseva I, Vacanti JP. Tissue engineering and its potential impact on surgery.World J Surg 2001;25(11): 1458-66

[224] Norotte C, Marga FS, Niklason LE, Forgacs G. Scaffold-free vascular tissue engineering using bioprinting.Biomaterials 2009;30(30): 5910-7 
[225] Masoumi N, Jean A, Zugates JT, Johnson KL, Engelmayr GC Jr. Laser microfabricated poly(glycerol sebacate) scaffolds for heart valve tissue engineering.J Biomed Mater Res A 2012. doi: 10.1002/jbm.a.34305

[226] Schmauss D, Schmitz C, Bigdeli AK, Weber S, Gerber N, Beiras-Fernandez A, Schwarz F, Becker C, Kupatt C, Sodian R. Three-dimensional printing of models for preoperative planning and simulation of transcatheter valve replacement. Ann Thorac Surg2012;93(2): e31-3

[227] Nakayama Y, Yamanami M, Yahata Y, Tajikawa T, Ohba K, Watanabe T, Kanda K, Yaku H. Preparation of a completely autologous trileaflet valve-shaped construct by in-body tissue architecture technology. J Biomed Mater Res B Appl Biomater 2009;91(2): 813-8

[228] Davies H. Catheter mounted valve for temporary relief of aortic insufficiency Lancet 1965;1: 250

[229] Bonhoeffer P, Boudjemline Y, Saliba Z, Merckx J, Aggoun Y, Bonnet D, Acar P, Le Bidois J, Sidi D, Kachaner J. Percutaneous replacement of pulmonary valve in a rightventricle to pulmonary-artery prosthetic conduit with valve dysfunction.Lancet2000;356(9239): 1403-5

[230] Cribier A, Eltchaninoff H, Bash A, Borenstein N, Tron C, Bauer F, Derumeaux G, Anselme F, Laborde F, Leon MB. Percutaneous transcatheter implantation of an aortic valve prosthesis for calcific aortic stenosis: first human case description.Circulation2002;106(24): 3006-8

[231] Schmidt D, Dijkman PE, Driessen-Mol A, Stenger R, Mariani C, Puolakka A, Rissanen M, Deichmann T, Odermatt B, Weber B, Emmert MY, Zund G, Baaijens FP, Hoerstrup SP. Minimally-invasive implantation of living tissue engineered heart valves: a comprehensive approach from autologous vascular cells to stem cells.J Am Coll Cardiol2010;56(6): 510-20

[232] Schmidt D, Dijkman PE, Driessen-Mol A, Stenger R, Mariani C, Puolakka A, Rissanen M, Deichmann T, Odermatt B, Weber B, Emmert MY, Zund G, Baaijens FP, Hoerstrup SP. Minimally-invasive implantation of living tissue engineered heart valves: a comprehensive approach from autologous vascular cells to stem cells.J Am Coll Cardiol2010;56(6): 510-20

[233] Helmchen F, Denk W. Deep tissue two-photon microscopy. Helmchen F, Denk W. Nat Methods 2005;2(12): 932-40

[234] Schenke-Layland K, Riemann I, Opitz F, König K, Halbhuber KJ, Stock UA. Comparative study of cellular and extracellular matrix composition of native and tissue engineered heart valves.Matrix Biol 2004;23(2): 113-25

[235] Karamitsos TD, Myerson SG. The role of cardiovascular magnetic resonance in the evaluation of valve disease.Prog Cardiovasc Dis 2011;54(3): 276-86 
[236] Dohmen PM, Lembcke A, Hotz H, Kivelitz D, Konertz WF. Ross operation with a tissue-engineeredheart valve.Ann Thorac Surg 2002;74(5):1438-42

[237] Ramaswamy S, Schornack PA, Smelko AG, Boronyak SM, Ivanova J, Mayer JE Jr, Sacks MS. Superparamagnetic iron oxide (SPIO) labeling efficiency and subsequent MRI tracking of native cell populations pertinent to pulmonary heart valve tissue engineering studies.NMR Biomed 2012;25(3): 410-7

[238] Aikawa E, Otto CM. Look more closely at the valve: imaging calcific aortic valve disease.Circulation2012;125(1): 9-11

[239] Liu L, Gardecki JA, Nadkarni SK, Toussaint JD, Yagi Y, Bouma BE, Tearney GJ. Imaging the subcellular structure of human coronary atherosclerosis using micro-opticalcoherencetomography.Nat Med 2011;17(8): 1010-4

[240] Ruggiero A, Thorek DL, Guenoun J, Krestin GP, Bernsen MR. Cell tracking in cardiac repair: what to image and how to image. Eur Radiol 2012;22(1): 189-204

[241] Ross DN. Homograft replacement of the aortic valve. Lancet 1962;2(7254): 487

[242] Jashari R, Tabaku M, Van Hoeck B, Cochéz C, Callant M, Vanderkelen A. Decontamination of heart valve and arterial allografts in the European Homograft Bank (EHB): comparison of two different antibiotic cocktails in low temperature conditions.Cell Tissue Bank 2007;8(4): 247-55

[243] Soo A, Healy DG, El-Bashier H, Shaw S, Wood AE. Quality control in homograft valve processing: when to screen for microbiological contamination?Cell Tissue Bank 2011;12(3): 185-90

[244] Jashari R, Goffin Y, Van Hoeck B, Vanderkelen A, du Verger A, Fan Y, Holovska V, Fagu A, Brahy O. Belgian and European experience with the European Homograft Bank (EHB) cryopreserved allograft valves.--assessment of a 20 year activity.Acta Chir Belg 2010;110(3): 280-90

[245] Wassenaar C, Bax WA, van Suylen RJ, Vuzevski VD, Bos E. Effects of cryopreservation on contractile properties of porcine isolated aortic valve leaflets and aortic wall.J Thorac Cardiovasc Surg 1997;113(1): 165-72

[246] Rendal Vázquez ME, Díaz Román TM, Rodríguez Cabarcos M, Zavanella Botta C, Domenech García N, González Cuesta M, Sánchez Dopico MJ, Pértega Díaz S, Andión Núñez C. Apoptosis in fresh and cryopreserved cardiac valves of pig samples.Cell Tissue Bank 2008;9(2): 101-7

[247] Gatto C, Dainese L, Buzzi M, Terzi A, Guarino A, Pagliaro PP, Polvani G, D'Amato Tothova J. Establishing a procedure for dimethyl sulfoxide removal from cardiovascular allografts: a quantitative study.Cell Tissue Bank 2012 Jul 27 [Epub ahead of print] 
[248] Gerson CJ, Elkins RC, Goldstein S, Heacox AE. Structural integrity of collagen and elastin in SynerGraft ${ }^{\circledR}$ decellularized-cryopreserved human heart valves.Cryobiology. 2012 Feb;64(1):33-42

[249] Schenke-Layland K, Madershahian N, Riemann I, Starcher B, Halbhuber KJ, König K, Stock UA. Impact of cryopreservation on extracellular matrix structures of heart valve leaflets.Ann Thorac Surg 2006;81(3): 918-26

[250] Lisy M, Pennecke J, Brockbank KG, Fritze O, Schleicher M, Schenke-Layland K, Kaulitz R, Riemann I, Weber CN, Braun J, Mueller KE, Fend F, Scheunert T, Gruber AD, Albes JM, Huber AJ, Stock UA. The performance of ice-free cryopreserved heart valve allografts in an orthotopic pulmonary sheep model.Biomaterials 2010;31(20): 5306-11

[251] Rattazzi M, Iop L, Faggin E, Bertacco E, Zoppellaro G, Baesso I, Puato M, Torregrossa G, Fadini GP, Agostini C, Gerosa G, Sartore S, Pauletto P. Clones of interstitial cells from bovine aortic valve exhibit different calcifying potential when exposed to endotoxin and phosphate.Arterioscler Thromb Vasc Biol 2008;28(12): 2165-72

[252] Bertacco E, Millioni R, Arrigoni G, Faggin E, Iop L, Puato M, Pinna LA, Tessari P, Pauletto P, Rattazzi M. Proteomic analysis of clonal interstitial aortic valve cells acquiring a pro-calcific profile.J Proteome Res 2010;9(11): 5913-21

[253] New SE, Aikawa E. Cardiovascular calcification: an inflammatory disease.Circ J 2011;75(6): 1305-13

[254] Mathapati S, Verma RS, Cherian KM, Guhathakurta S.Inflammatory responses of tissue-engineered xenografts in a clinical scenario.Interact Cardiovasc Thorac Surg2011;12(3): 360-5

[255] Zhou J, Fritze O, Schleicher M, Wendel HP, Schenke-Layland K, Harasztosi C, Hu S, Stock UA. Impact of heart valve decellularization on 3-D ultrastructure, immunogenicity and thrombogenicity. Biomaterials 2010;31(9): 2549-54

[256] Arai S, Orton EC. Immunoblot detection of soluble protein antigens from sodium dodecyl sulphate- and sodium deoxycholate-treated candidate bioscaffold tissues. J Heart Valve Dis 2009;18(4): 439-43

[257] Barth PJ, KoÅNster H, Moosdorf R. CD34+ fibrocytes in normal mitral valves and myxomatous mitral valve degeneration. Pathol Res Pract 2005;201(4): 301-4

[258] Orkin SH. Diversification of haematopoietic stem cells to specific lineages. Nat Rev Genet 2000;1(1): 57-64

[259] Iop L, Basso C, Rizzo S, Piccoli M, Callegari M, Paolin A, De Coppi P, Thiene G, Sartore S, Gerosa G. Stem Cell Populations in Human Heart Valves: Identification, Isolation and Characterization in Valve Homografts and Surgical Specimens. Conference proceedings. World Conference on Regenerative Medicine- Leipzig, Germany, 29-31 October 2009 
[260] Martinez FO, Sica A, Mantovani A, Locati M. Macrophage activation and polarization. Front Biosci 2008;13: 453-61

[261] Brown BN, Valentin JE, Stewart-Akers AM, McCabe GP, Badylak SF. Macrophage phenotype and remodeling outcomes in response to biologic scaffolds with and without a cellular component.Biomaterials 2009;30(8):1482-91

[262] Zheng C, Azcutia V, Aikawa E, Figueiredo JL, Croce K, Sonoki H, Sacks FM, Luscinskas FW, Aikawa M. Statins suppress apolipoprotein CIII-induced vascular endothelial cell activation and monocyte adhesion.Eur Heart J 2012 Aug 26 [Epub ahead of print]

[263] Monaghan M, Pandit A. RNA interference therapy via functionalized scaffolds. Adv Drug Deliv Rev 2011;63(4-5):197-208 